\title{
Radiative and thermodynamic responses to aerosol extinction profiles during the pre-monsoon month over South Asia
}

\author{
Y. Feng ${ }^{1}$, V. R. Kotamarthi ${ }^{1}$, R. Coulter ${ }^{1}$, C. Zhao ${ }^{2}$, and M. Cadeddu ${ }^{1}$ \\ ${ }^{1}$ Environmental Science Division, Argonne National Laboratory, Argonne, IL, USA \\ ${ }^{2}$ Atmospheric Science and Global Change Division, Pacific Northwest National Laboratory, Richland, WA, USA \\ Correspondence to: Y. Feng (yfeng@anl.gov)
}

Received: 10 April 2015 - Published in Atmos. Chem. Phys. Discuss.: 19 June 2015

Revised: 18 November 2015 - Accepted: 8 December 2015 - Published: 18 January 2016

\begin{abstract}
Aerosol radiative effects and thermodynamic responses over South Asia are examined with the Weather Research and Forecasting model coupled with Chemistry (WRF-Chem) for March 2012. Model results of aerosol optical depths (AODs) and extinction profiles are analyzed and compared to satellite retrievals and two ground-based lidars located in northern India. The WRF-Chem model is found to heavily underestimate the AOD during the simulated premonsoon month and about $83 \%$ of the model's low bias is due to aerosol extinctions below $\sim 2 \mathrm{~km}$. Doubling the calculated aerosol extinctions below $850 \mathrm{hPa}$ generates much better agreement with the observed AOD and extinction profiles averaged over South Asia. To separate the effect of absorption and scattering properties, two runs were conducted: in one run (Case I), the calculated scattering and absorption coefficients were increased proportionally, while in the second run (Case II) only the calculated aerosol scattering coefficient was increased. With the same AOD and extinction profiles, the two runs produce significantly different radiative effects over land and oceans. On the regional mean basis, Case I generates $48 \%$ more heating in the atmosphere and $21 \%$ more dimming at the surface than Case II. Case I also produces stronger cooling responses over the land from the longwave radiation adjustment and boundary layer mixing. These rapid adjustments offset the stronger radiative heating in Case I and lead to an overall lower-troposphere cooling up to $-0.7 \mathrm{~K} \mathrm{day}^{-1}$, which is smaller than that in Case II. Over the ocean, direct radiative effects dominate the heating rate changes in the lower atmosphere lacking such surface and lower atmosphere adjustments due to fixed sea surface temperature, and the strongest atmospheric warming is obtained in Case I. Consequently, atmospheric dynamics (boundary
\end{abstract}

layer heights and meridional circulation) and thermodynamic processes (water vapor and cloudiness) are shown to respond differently between Case I and Case II, underlining the importance of determining the exact portion of scattering or absorbing aerosols that lead to the underestimation of aerosol optical depth in the model. In addition, the model results suggest that both the direct radiative effect and rapid thermodynamic responses need to be quantified for understanding aerosol radiative impacts.

\section{Introduction}

South Asia, including the Indian subcontinent and adjacent oceans, is a regional hotspot with high aerosol loadings (Ramanathan et al., 2001; Moorthy et al., 2013). Aerosols over this region are composed of locally emitted sulfate, black carbon (BC), and organic substances (mainly from industrial, transportation, residential, and agricultural burning), as well as long-range-transported desert dust and sea spray aerosols. These aerosols together induce a large negative radiative forcing at the top of the atmosphere (TOA) through direct scattering and absorption of incoming solar radiation. With year 2000 emissions, Chung et al. (2010) estimated the regional TOA aerosol forcing in South Asia at about $-1.9 \mathrm{~W} \mathrm{~m}^{-2}$, which is larger by several factors than the present-day global mean direct forcing (Boucher et al., 2013). The overall aerosol cooling effect in response to negative TOA forcing is suggested to weaken the sea surface temperature gradient over the Indian Ocean and decelerate the monsoonal circulation and moisture transport (Ramanathan et al., 2005). Other studies show that local warm- 
ing by $\mathrm{BC}$ in the upper troposphere intensifies vertical motion over land and modulates intraseasonal monsoon rainfall variations (Lau et al., 2006). Therefore, rapidly increased anthropogenic aerosol emissions in South Asia have been linked closely to observed changes in surface temperature and rainfall patterns in global climate simulations (Meehl et al., 2008; Lau et al., 2009; Wang et al., 2009; Bollasina et al., 2011; Ganguly et al., 2012).

For quantifying aerosol direct perturbations in the radiation budget, column-integrated aerosol optical depth (AOD) is often examined in global models, some of which include regional analysis over South Asia (Myhre et al., 2009, 2013; Shindell et al., 2013; Boucher et al., 2013; Pan et al., 2015) and in regional-scale models (Chung et al., 2010; Nair et al., 2012; Kumar et al., 2014). Besides AOD, aerosol singlescattering albedo (SSA) has also been identified as a main source of uncertainty in estimates of aerosol direct forcing (McComiskey et al., 2008; Loeb and Su, 2010) and evaluated with observations. Most models underpredict aerosol abundances over South Asia vs. data from the ground-based Aerosol Robotic Network (AERONET) (Holben et al., 1998) or satellite-retrieved AOD observations such as the Moderate Resolution Imaging Spectroradiometer (MODIS) (e.g., Yu et al., 2003; Kinne et al., 2006; Koch et al., 2009; Ganguly et al., 2012). In addition, models also tend to underestimate aerosol absorption by overestimating the SSA (Liu et al., 2012). Such low biases in aerosol optical properties might potentially affect model simulations of regional climatology and assessment of aerosol climate impacts over the South Asia region.

Vertical distribution of aerosols is another important parameter in determining aerosol-radiation interactions. When column AOD is constrained, uncertainties in aerosol vertical profiles can still contribute to significant uncertainties in the calculation of radiative forcing (Lohmann and Feichter, 2001; Zarzycki and Bond, 2010; Ban-Weiss et al., 2012). The extent to which the aerosol profile impacts aerosol radiative effects depends on the presence of cloud, surface albedo, and SSA. Column and global aerosol and radiation models have been used to explore the sensitivity of aerosol direct radiative forcing to the vertical distribution of aerosols, especially absorbing aerosols, relative to clouds (Haywood and Shine, 1997; Liao and Seinfeld, 1998; Samset et al., 2013; Vuolo et al., 2014; Choi and Chung, 2014). However, compared to column AOD and SSA, aerosol vertical distributions are evaluated less frequently against observations, partly due to a lack of observational data sets.

Aircraft profiling of aerosol concentrations from recent airborne experiments, such as the HIAPER Pole-to-Pole Observations (Schwarz et al., 2010) and the Arctic Research of the Composition of the Troposphere from Aircraft and Satellites (Jacob et al., 2010), provides high-quality data sets for model comparison (e.g., Koch et al., 2009; Liu et al., 2012). However, these data sets are usually available only for limited locations and time periods. In particular, few long-term aircraft surveys are available for South Asia, other than a few past field experiments such as the Maldives Autonomous Unmanned Aerial Vehicle Campaign (Ramanathan et al., 2007) and the Integrated Campaign for Aerosol, Gases and Radiation Budget experiment (Satheesh et al., 2009). Satelliteretrieved aerosol extinction profiles providing wide coverage in space and time have been used increasingly for model evaluation. Using the Cloud-Aerosol Lidar and Infrared Pathfinder Satellite Observations (CALIPSO) lidar nighttime data at $532 \mathrm{~nm}$ in cloud-free conditions from June 2006 to November 2007, Yu et al. (2010) evaluated aerosol extinction profiles simulated by the Goddard Chemistry Aerosol Radiation Transport (GOCART) model and found substantial underestimation in the magnitude of aerosol extinctions over the Indian subcontinent. Similar analysis of all-sky CALIPSO nighttime data in the AeroCom (Aerosol Comparisons between Observations and Models) multi-model evaluation of the vertical distribution of aerosols (Koffi et al., 2012) found that 11 of the 12 AeroCom models underestimated the annual mean aerosol extinctions below $2 \mathrm{~km}$ over South Asia. A recent study by Quennehen et al. (2015) examined six global and one regional models with CALIPSOderived backscatter profiles at $532 \mathrm{~nm}$ during August and September 2008, and the multi-model mean backscatter is also underestimated between 0 and $2 \mathrm{~km}$ over northern India and eastern China.

Although these model-data comparisons help to identify the biases in model simulations of aerosol extinction or concentration profiles, the resultant changes in atmospheric heating, dynamics, and cloud adjustments (the aerosol semidirect effects) have yet to be investigated. Moreover, satellite retrievals of aerosol extinction profiles are also subject to uncertainties associated with cloud contamination, surface overlap correction, and daylight background noise. Observational studies have examined atmospheric heating rates extensively by using aerosol extinctions retrieved from groundbased or CALIPSO lidar instruments (Misra et al., 2012; Gautam et al., 2010; Kuhlmann and Quaas, 2010) and in situ aircraft data (Ramana et al., 2007; Satheesh et al., 2008). These studies directly provide observational constraints on the instantaneous atmospheric heating caused by aerosols, ranging from 0.35 to $2 \mathrm{~K} \mathrm{day}^{-1}$, in the South Asia region. On the other hand, observational methods face challenges in distinguishing the rapid adjustments in the atmosphere attributable to aerosols vs. other environmental influences.

In the present study, we examine the atmospheric radiative and thermodynamic responses to uncertainty associated with vertical distributions of aerosol extinction coefficient by correcting bias in model calculations with satellite and surface remote sensing data. This not only identifies discrepancies between the model-predicted and observed aerosol optical properties as a function of height but also demonstrates the potential importance of aerosol-related uncertainty for regional climate simulations. The regional Weather Research and Forecasting (WRF) model, coupled with a 
chemistry module (WRF-Chem), is used to simulate the premonsoon month of March 2012 over South Asia. The next section describes the regional climate model configurations and ground-based and satellite data sets available. Section 3 evaluates the modeled and observed AODs and aerosol profiles and discusses changes in the simulated radiative energy balance, surface temperature, lower-atmospheric heating rates, boundary layer (BL) height, large-scale circulation, and cloud occurrence, in response to optimized matching of aerosol extinction profiles to observations. The main findings of this study and implications for future work are summarized in Sect. 4.

\section{Methodology}

\subsection{Model description}

This study uses a version of the WRF-Chem 3.3 (Skamarock et al., 2008; Grell et al., 2005), coupled with the chemistry module MOZCART (Pfister et al., 2011), to simulate aerosol distributions, aerosol-radiation interactions, and regional meteorological fields. The default model simulations are performed for 8 months from August 2011 to March 2012, the period when multi-instrumental aerosol observations were collected by the US Department of Energy (DOE) Ganges Valley Aerosol Experiment (GVAX) at a mountain-top site, Nainital $\left(29^{\circ} \mathrm{N}, 79^{\circ} \mathrm{E} ; 1939 \mathrm{~m}\right.$ above mean sea level (a.m.s.l.)), in northern India. The model domain is configured from 55 to $95^{\circ} \mathrm{E}$ and 0 to $36^{\circ} \mathrm{N}$, with a horizontal grid spacing of $\sim 12 \mathrm{~km}$ and 27 vertical layers. The MOZCART chemistry module (WRF-Chem Version 3.7 User's guide: http://ruc.noaa.gov/wrf/WG11/Users_ guide.pdf) includes the MOZART-4 gas-phase chemistry (Emmons et al., 2010) and the GOCART bulk aerosol scheme (Chin et al., 2002). MOZCART simulates externally mixed aerosol species including sulfate, BC, organic carbon (OC), dust (in five size bins with $0.5,1.4,2.4,4.5$, and $8 \mu \mathrm{m}$ effective radius), and sea salt (in 4 size bins with $0.3,1.0,3.2$, and $7.5 \mu \mathrm{m}$ effective radius). This version of the WRF-Chem aerosol and chemistry modules has been used and evaluated in studying effects of dust aerosols on tropospheric chemistry during the pre-monsoon season in northern India (Kumar et al., 2014).

The anthropogenic emissions of gaseous species are derived from the Reanalysis of the Tropospheric Chemical Composition and Emissions Database for Global Atmospheric Research compiled for the year 2000. The default emissions of $\mathrm{BC}, \mathrm{OC}$, and $\mathrm{SO}_{2}$ are same as in the GOCART model for year 2006. Over India, emissions of BC, OC, and $\mathrm{SO}_{2}$ are replaced with year 2010 inventories available at resolutions of $0.1^{\circ} \times 0.1^{\circ}$ for anthropogenic sources and $0.5^{\circ} \times 0.5^{\circ}$ for biomass burning (Lu et al., 2011). The total emissions of BC and OC used in this study are about 1.12 and $3.06 \mathrm{Gg} \mathrm{yr}^{-1}$ over India, respectively, roughly 51 and $63 \%$ higher than those from the default GOCART global inventories $\left(0.74\right.$ and $\left.1.88 \mathrm{Gg} \mathrm{yr}^{-1}\right)$. The total $\mathrm{SO}_{2}$ emissions in South Asia with updated emissions over India are $9.36 \mathrm{Gg} \mathrm{yr}^{-1}$, slightly less than the default GOCART emissions $\left(10 \mathrm{Gg} \mathrm{yr}^{-1}\right)$. Additional sulfate emissions from waste and biofuel burning (Yevich and Logan, 2003) are also included (about $0.21 \mathrm{Gg} \mathrm{yr}^{-1}$ ). Dimethyl sulfide, dust, and sea salt emissions are calculated online as for the GOCART model (Ginoux et al., 2001; Chin et al., 2002). Primary aerosol emissions including all the anthropogenic, biomass burning, and natural sources are injected into the lowest level of the model and transported by advection and updrafts. Calculations of optical properties of aerosols assume internal mixing (Fast et al., 2006) including the Kappa-based hygroscopic growth of aerosol components (Petters and Kreidenweis, 2007), although aerosols are transported as external mixtures. The Rapid Radiative Transfer Model for General Circulation Models schemes (Iacono et al., 2008) is used for shortwave and longwave radiation calculations (Zhao et al., 2011). Other main physical packages used in this study are the Thompson cloud microphysics (Thompson et al., 2008), the Zhang-McFarlane cumulus parameterization (Zhang and McFarlane, 1995), the Mellor-Yamada-Janjic BL scheme (Janjic, 1994), and the Rapid Update Cycle land surface model (Benjamin et al., 2004).

The initial and boundary conditions of meteorological fields were interpolated to the model time step ( $72 \mathrm{~s}$ ) from the compiled $6 \mathrm{~h}$ National Centers for Environmental Prediction reanalysis data available at $1^{\circ} \times 1^{\circ}$ resolution. Outputs from the MOZART-4 global chemical transport model (Emmons et al., 2010) generated for the simulation time periods are used for chemistry initial and boundary conditions. Radiative feedbacks of aerosols are coupled with the meteorology updates at each model time step. Indirect aerosol microphysical effects are not considered. While this omission might affect the simulated total aerosol radiative impact, the focus here is on examination of the model's sensitivity to uncertainty in predicted aerosol extinction, which, as an aerosol optical property, has a direct impact on aerosol direct and semi-direct radiative effects more than aerosol microphysical effect.

The model-data analysis and discussions here center on simulations in March 2012, for two reasons. First, during this pre-monsoon month, ground-based lidar measurements are available at Nainital and Kanpur (in northern India) and used with satellite observations to characterize bias in the calculated aerosol extinctions. As discussed later, it is important to have independently calibrated ground-based measurements because of the uncertainty associated with satellite data. Second, we examine the model's performance in simulating AOD and vertical distributions for this pre-monsoon month, because the anthropogenic aerosol concentrations over this period are among the highest of the year and impose large radiative forcing (Ramanathan et al., 2007). Uncertainty in aerosol predictions might propagate into the predicted meteorological fields and influence the moisture distribution in 
the pre-monsoon-to-monsoon season. In addition to the default (control) run for March, two sensitivity model simulations are conducted with corrected extinction profiles, as described below. One-week spin-up is used for initializing the 1-month runs.

\subsection{Observational data sets}

During the GVAX experiment, the DOE Atmospheric Radiation Measurements (ARM) Program Mobile Facility 1 (AMF-1) was operated at Nainital in the central Himalayan region of northern India. Located at $\sim 1939 \mathrm{~m}$ above sea level, this site was frequently near the planetary BL top or in the free troposphere during the experimental period. Groundbased AMF-1 multi-filter rotating shadowband radiometer (MFRSR) measurements were made from September 2011 to March 2012. The post-processed, quality-assured AOD products (pghmfrsraod1michM1.s1) from the MFRSR are used to evaluate the model simulations of monthly and daily mean daytime (06:00-18:00 local time) AODs. Instrumental uncertainty in the MFRSR-retrieved AOD is about 0.026 above $380 \mathrm{~nm}$ (Schmid et al., 1999), which is generally below the typical AOD levels observed at this site. Monthly mean AERONET (Holben et al., 1998) level 2 sun photometer AOD data sets that are also used have a reported uncertainty of approximately 0.01 at $500 \mathrm{~nm}$ (Eck et al., 1999; Smirnov et al., 2000). Comparisons of the simulated monthly mean AODs with Moderate Resolution Imaging Spectroradiometer (MODIS)/Terra satellite observations (MOD08 level 3, edition 5; Platnick et al., 2003) are used to evaluate the geographic distribution of AOD.

Vertical profiles of aerosol extinction at $532 \mathrm{~nm}$ are retrieved at Nainital from micropulse lidar (MPL) backscatter measurements and MFRSR AOD data for March 2012, according to Kafle and Coulter (2013) and Klett (1981). After exclusion of cloud contamination and missing data, 26 days of MPL-retrieved extinction profiles remain, 25 of which have valid data during the daytime when MFRSR AOD retrievals are available. The $30 \mathrm{~min}$ frequency extinction retrievals are averaged hourly and monthly for model comparison with a vertical resolution of $\sim 500 \mathrm{~m}$. Aerosol extinction profiles at $532 \mathrm{~nm}$ are also available at a nearby low-elevation site, Kanpur $\left(26.5^{\circ} \mathrm{N}, 80.3^{\circ} \mathrm{E} ; 120 \mathrm{~m}\right.$ a.m.s.l.), from the National Aeronautics and Space Administration's MPL network (MPLNET; Welton et al., 2001). Unlike Nainital, which is located near the BL top, the Kanpur site provides aerosol characteristics close to the surface pollution sources in the Indo-Gangetic Basin. During winter and the pre-monsoon season, this site is often loaded with high concentrations of anthropogenic aerosols mixed with dust from episodic events (Dey and Di Girolamo, 2010). The quality-assured MPLNET level 2 daytime products are available from August 2011 to March 2012 for model comparison. In addition to the ground-based remote sensing data, CALIPSO satellite retrievals of extinction profiles from the Cloud-Aerosol Lidar with Orthogonal Polarization sensor (Winker et al., 2009), version 3 , level 2 nighttime products are also used to characterize regional variations in aerosol vertical distribution. Uncertainties associated with these lidar retrievals of aerosol extinction profiles, either space-borne or ground-based, include overlapping corrections near the surface, signal-tonoise ratio in the background (Welton and Campbell, 2002), and propagated errors in AOD measurements (Kafle and Coulter, 2013). The observations of extinction profiles are used mainly to identify and correct systematic bias in the model-simulated monthly mean vertical profiles of aerosols. The aerosol abundances in the column are constrained with column-integrated AOD measurements from MFRSR and MODIS.

\section{Results}

\subsection{Aerosol optical depth}

The model simulations of monthly mean AOD for March 2012 are compared with the MODIS/Terra satellite observations in Fig. 1. During this time of the year, the IndoGangetic Valley is impacted with locally emitted aerosols from urban and industrial sources as well as dust mainly from nearby arid agricultural lands and deserts (Giles et al., 2011). As shown in Fig. 1a, the MODIS retrievals of AOD are generally larger than 0.5 in these areas. Given the dry premonsoon conditions with small wet removal, these aerosols are transported in long distance by the northwesterly winds prevailing in the valley. That leads to similarly high AODs $(>0.5)$ over to the Bay of Bengal and the eastern India in the MODIS observations. Another aerosol hotspot is off the southwest coast of the Indian subcontinent, influenced by both nearby anthropogenic emissions in western India and long-range transported pollution from northern India (Ramanathan et al., 2001). Dust dominates the AOD observed over the Arabian Sea with values about 0.3-0.5.

The model-calculated AODs (shown in Fig. 1b) are lower than MODIS retrievals over most of the domain, while the overall geographic pattern of AOD distributions is simulated except for over the Arabian Sea. Large AODs are predicted in northern and eastern India and along the pathway that the aerosol plumes travel to southwestern India and downwind as depicted similarly in the MODIS observations. But the maximum AOD values calculated by the model are much lower around 0.3-0.4. AODs less than 0.1 are predicted over most of northwestern India and the adjacent oceans, whereas MODIS has much higher values $(>0.3)$. These discrepancies could be attributable to episodic dust activities not reproduced by WRF-Chem (as shown in Fig. S1 in the Supplement that dust aerosols are dominant species) or to overestimation associated with the MODIS satellite retrievals over highly reflective surfaces such as deserts and clouds over the ocean. In other aerosol-concentrated regions, anthropogenic pollutants 
(a)

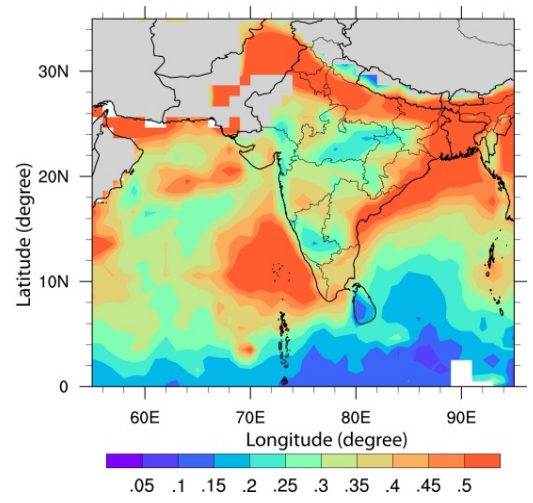

(c)

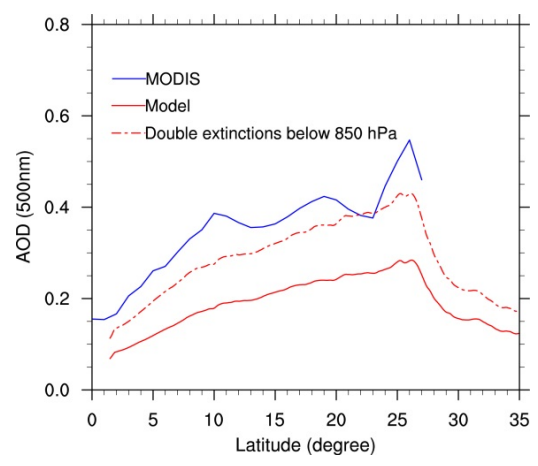

(b)

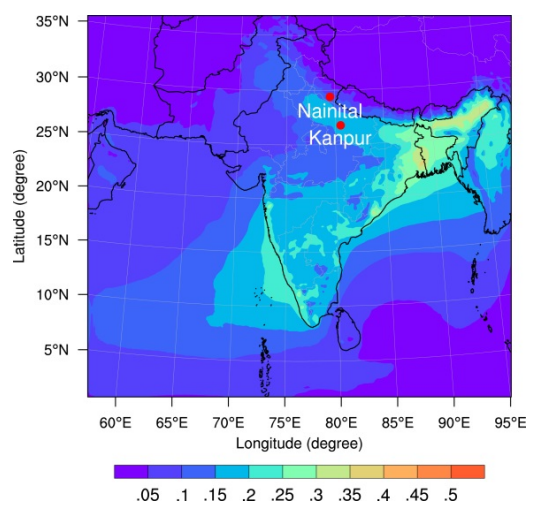

(d)

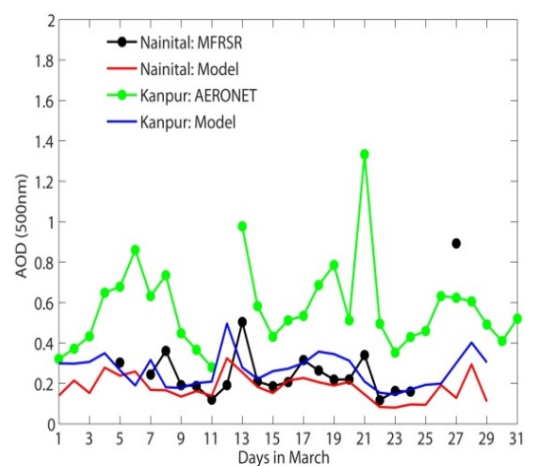

Figure 1. For March 2012: (a) MODIS-retrieved and (b) simulated monthly mean AOD distributions over South Asia. The locations of Nainital and Kanpur sites are indicated by red dots. (c) Latitudinal variations in AOD averaged for $60-95^{\circ} \mathrm{E}$ from the model control run (red solid), sensitivity runs (red dotted dash), and MODIS retrievals (blue). North of $27^{\circ} \mathrm{N}$, more than two-thirds of the MODIS AODs are missing (data not shown). (d) Comparison of simulated and observed daily mean AOD at Nainital and Kanpur

such as sulfate, $\mathrm{BC}$, and $\mathrm{OC}$ are the main contributors to the AOD underestimation (Fig. S1).

The degree to which the model-calculated AOD is lower than the MODIS data is further shown in Fig. 1c for March 2012. The figure compares the latitudinal variations in AOD averaged between 60 and $95^{\circ} \mathrm{E}$. The default model (control run) calculations of AOD are systematically smaller than the MODIS data (by about a factor of 2), from the Equator northward to $27^{\circ} \mathrm{N}$ (latitudes north of $27^{\circ} \mathrm{N}$ are not shown for the MODIS data, because more than two-thirds of the data are missing). Despite the underestimation in absolute AODs, a gradient in AOD calculated as a function of latitude is similar to the MODIS observations, increasing by about $\sim 0.1 \mathrm{AOD}$ every $10^{\circ}$ in latitude. In addition, the calculated daily daytime mean AODs are compared in Fig. 1d with ground-based GVAX MFRSR measurements at Nainital and AERONET data at nearby Kanpur $(\sim 390 \mathrm{~km}$ southeast; locations of the two sites are marked in Fig. 1b). Being a relatively clean site, Nainital has a monthly mean AOD of 0.232 from MFRSR measurements, while the mean AERONET AOD is 0.583 at Kanpur. The discrepancies between the modeled and observed AOD are much smaller at the Nainital site. The monthly mean AOD at Nainital is estimated at 0.181 by WRF-Chem - about $22 \%$ lower than the MFRSR AOD - and the model-data difference is only $13 \%$ if the outlier on day 27 of the observations is excluded. In contrast, the model's underestimation at Kanpur is about $54 \%$, which is more close to the zonal-mean differences shown in Fig. 1c. These differences in AOD comparison imply that WRF-Chem tends to underpredict aerosol extinction (whose vertical integral is AOD) at lower elevations (in the $\mathrm{BL}$ ) more than in the free troposphere over this region, as the Nainital data are more representative of the atmosphere near or above the BL top.

Similar underestimation in the modeled AOD compared with the MODIS observations is also found for other months between August 2011 and March 2012 (Fig. S2 in the Supplement). The AOD underestimation is one of the common problems in aerosol model simulations for post-monsoon and winter time periods over the South Asian region. Pan et al. (2015) suggested several possible causes including suppression of the aerosol hygroscopic growth and formation of secondary inorganic aerosol due to low-biased relative humidity in the boundary layer (Feng et al., 2016), omission of 
(a) Nainital

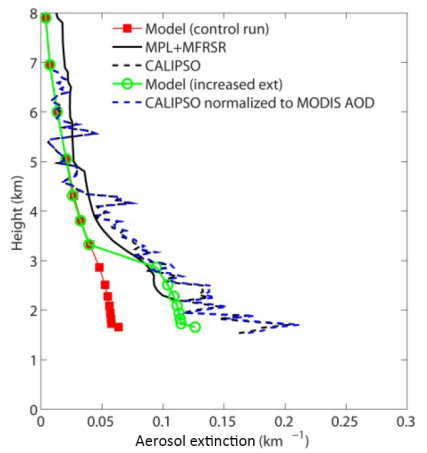

(d) Nainital

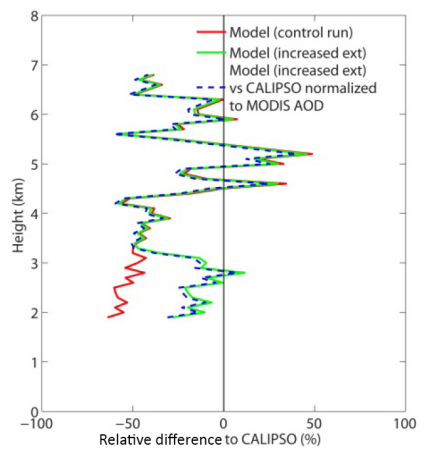

(b) Kanpur

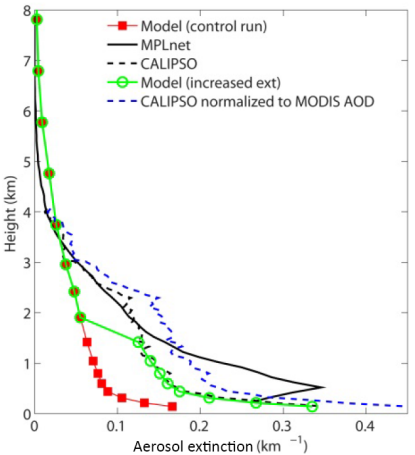

(e) Kanpur

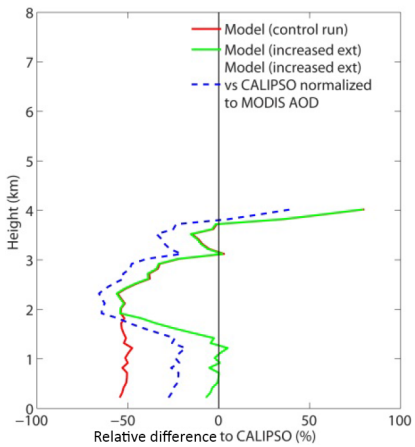

(c) South Asia

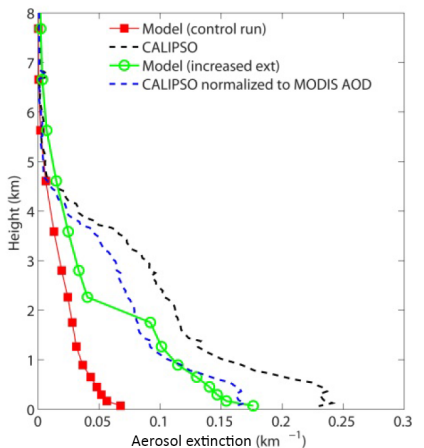

(f) South Asia

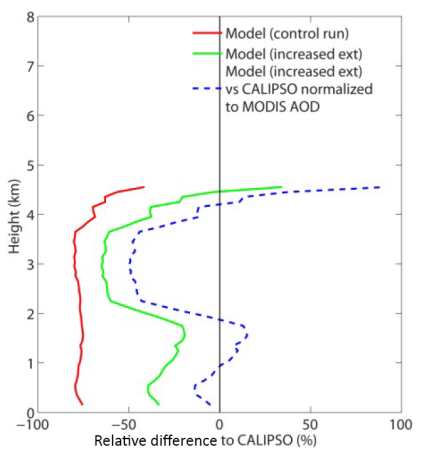

Figure 2. Comparisons of monthly mean aerosol extinction profiles from model calculations at $550 \mathrm{~nm}$ (red squares for the control run and green open circles for the sensitivity studies), ground-based MPL data at $532 \mathrm{~nm}$ (solid black), satellite-retrieved CALIPSO data at $532 \mathrm{~nm}$ (dashed black), and CALIPSO data normalized to the MODIS AODs (dashed blue) (a) at Nainital, (b) at Kanpur, and (c) over South Asia $\left(60-95^{\circ} \mathrm{E}, 0-30^{\circ} \mathrm{N}\right)$, respectively. The column-mean uncertainty in CALIPSO extinction data is $\pm 110, \pm 93$, and $\pm 91 \%$ in panels (a) $-(\mathbf{c})$; percent differences between the simulated and CALIPSO profiles are shown for (d) Nainital, (e) Kanpur, and (f) South Asia.

nitrate aerosol, and underestimated emissions from agricultural waste burning and biofuel usage. Resolving these differences in AOD is beyond the scope of this paper, which intends to identify the vertical location of the AOD biases and investigate the subsequent responses, but certainly deserves further investigation.

\subsection{Aerosol extinction profiles}

To further evaluate the vertical distribution of calculated aerosol extinctions $\left(b_{\text {ext }}\right)$, the ground-based MPL retrievals available in March 2012 at Nainital and Kanpur, along with CALIPSO satellite retrievals, are used. Figure 2 compares the simulated monthly mean vertical profiles of $b_{\text {ext }}$ with the observational data sets. Like column-integrated AOD, calculated aerosol extinctions are also lower at the high-elevation Nainital site (Fig. 2a), at the polluted surface Kanpur site (Fig. 2b), and as an average over the South Asia region (Fig. 2c). Moreover, the discrepancies between the modeled and observed profiles are larger in the lower atmosphere, where aerosols are more concentrated (as indicated by larger extinctions), than at higher altitudes in the free troposphere. These differences are further illustrated in Fig. 2d-f, which shows the percent differences in calculated extinction profiles relative to the CALIPSO data in the column. Table 1 summarizes the column-mean relative differences $(\%)$ between the predicted monthly mean $b_{\text {ext }}$ and retrievals from the CALIPSO data, expressed as

$$
\frac{\sum_{i=1}^{n} \frac{\left[b_{\text {ext,model }}(i)-b_{\text {ext,CALIPSO }}(i)\right]}{b_{\text {ext }, \text { CALIPSO }}(i)}}{n} \times 100,
$$

where $b_{\text {ext,CALIPSO }}>0.01$, and $i$ denotes the vertical levels from the surface up to $8 \mathrm{~km}$ (level $n$ ) at $0.1 \mathrm{~km}$ intervals. For altitudes below $850 \mathrm{hPa}$ (or $\sim 2-3 \mathrm{~km}$, depending on the location), the calculated average differences between the model control run and the CALIPSO data are $-56,-52$, and $-77 \%$ for Nainital, Kanpur, and South Asia, respectively. In comparison, smaller differences of $-33,-33$, and $-75 \%$, respectively, are estimated for the entire column.

The monthly mean extinction height $\left(z_{\alpha}\right)$, defined as $\frac{\sum_{i=1}^{n} b_{\mathrm{ext}, i} z_{i}}{\sum_{i=1}^{n} b_{\mathrm{ext}, i}}$

(Koffi et al., 2012), is also calculated in order to compare the modeled aerosol mean vertical structure with observations (Table 2). On a regional mean basis over South 
Table 1. Estimated differences relative to CALIPSO extinction profiles for Nainital, Kanpur, and South Asia in March 2012.

\begin{tabular}{lrrrrrrrr}
\hline & \multicolumn{2}{c}{ Column differences (\%) } & & \multicolumn{3}{c}{ Differences below 850 hPa (\%) } \\
\cline { 2 - 3 } Site & $\begin{array}{r}\text { Model } \\
\text { (control } \\
\text { run) }\end{array}$ & $\begin{array}{r}\text { Model } \\
\text { (increased } \\
\text { extinction) }\end{array}$ & $\begin{array}{r}\text { Model } \\
\text { (increased } \\
\text { extinction) }\end{array}$ & & $\begin{array}{r}\text { Model } \\
\text { (control } \\
\text { run) }\end{array}$ & $\begin{array}{r}\text { Model } \\
\text { (increased } \\
\text { extinction) }\end{array}$ & $\begin{array}{r}\text { Model } \\
\text { (increased } \\
\text { extinction) }\end{array}$ \\
\hline Nainital & -33 & -22 & -25 & & -56 & -12 & -16 \\
Kanpur & -33 & -14 & -33 & & -52 & -11 & -31 \\
S. Asia & -75 & -40 & -16 & & -77 & -30 & -0.4 \\
\hline
\end{tabular}

* Percent differences relative to the CALIPSO extinction profiles normalized to the column AOD inferred from the surface measurements for Nainital and Kanpur and the MODIS data for South Asia.

Table 2. Calculated mean extinction height $(\mathrm{km})$ from observations (MPL and CALIPSO) and model simulations over different regions in March 2012.

\begin{tabular}{|c|c|c|c|c|c|c|}
\hline & \multicolumn{6}{|c|}{ Calculated mean extinction height $(\mathrm{km})$} \\
\hline & Nainital & Kanpur & $\begin{array}{r}\text { Indo-Gangetic } \\
\text { Basin }\end{array}$ & $\begin{array}{r}\text { Central } \\
\text { India }\end{array}$ & $\begin{array}{l}\text { North } \\
\text { Indian } \\
\text { Ocean }\end{array}$ & $\begin{array}{r}\text { South } \\
\text { Asia }\end{array}$ \\
\hline MPL & 4.11 & 1.39 & - & - & - & - \\
\hline CALIPSO* & $3.55(3)$ & $1.48(4)$ & $1.53(9)$ & $1.74(4)$ & $1.09(5)$ & $1.70(29)$ \\
\hline Model (control run) & 4.00 & 2.09 & 1.86 & 1.91 & 1.73 & 1.85 \\
\hline Model (increased extinction) & 3.64 & 1.68 & 1.69 & 1.68 & 1.53 & 1.68 \\
\hline
\end{tabular}

* Numbers in the parentheses are the counts of CALIPSO tracks of the month.

Asia, $z_{\alpha}$ estimated from the March CALIPSO data is $1.7 \mathrm{~km}$ in this study. This value is consistent with the March-AprilMay mean extinction height of $1.99 \mathrm{~km}$ given by Koffi et al. (2012). However, model estimates of $z_{\alpha}$ in the control run are generally higher than those inferred from groundand satellite-based data sets over different locations/areas in South Asia, as shown in Table 2. The only exception is the comparison with MPL data at Nainital, with a slightly lower model-calculated $z_{\alpha}$. This might be due to spatial averaging differences between the $12 \mathrm{~km}$ grid mean model results and the point-based MPL data, because the comparison of $z_{\alpha}$ with the value estimated from CALIPSO for Nainital points to model overestimation, consistent with the other sites. The analysis of extinction profiles confirms model underestimation of column AOD in March and, moreover, indicates that the low bias in AOD arises mainly from calculated lower aerosol burden in the lower atmosphere, which leads to an AOD underestimate of $>50 \%$, irrespective of location. These differences between the observed and modeled profiles at low altitudes are generally larger than the uncertainties associated with ground-based measurements $(\sim 40 \%)$. Although the CALIPSO satellite retrievals indicate uncertainties of $\sim 91$ to $110 \%$, at the two ground sites their monthly mean values are comparable with the ground-based measurements. This validation provides support to the regional mean comparison with the CALIPSO data here, as no sufficient ground-based measurements are available on the regional scale. Comparison of the standard deviations in the daily extinction profiles (Fig. S3 in the Supplement) and two-sample $t$ test of daily aerosol extinction time series suggests that the differences between the model calculations and observations (MPL data for Nainital and Kanpur, and CALIPSO data for South Asia) are significant below $2.5 \mathrm{~km}$ with $p$ values less than the significance level of 0.05 (in the Supplement).

To examine potential impacts on calculated radiative and thermodynamic processes from the underestimation of aerosols, sensitivity model runs are conducted for March 2012 by optimizing matching of the observed aerosol vertical profiles. The calculated aerosol extinctions in the lowest eight model layers (below $\sim 850 \mathrm{hPa}$, at $1.5-3 \mathrm{~km}$ above sea level in the simulated model domain) are increased by a factor of 2 at each time step to reduce the identified low bias. However, there are no independent observations of aerosol absorption vertical profiles to constrain the model. AERONET SSA or the satellite-based absorption AOD retrievals provide constraints for column-integrated absorption properties, but neither of them resolves in altitude. To address this uncertainty, two approaches are tested for adjusting the extinction profiles. In Case I, the calculated scattering and absorption coefficients are increased proportionally, so that the altitude-dependent SSA - the fraction of scattering in total extinction - remains the same as in the control run. This case assumes that the underestimation of AOD is contributed proportionally by both scattering and absorbing aerosol load- 
ings. In Case II, only the calculated aerosol scattering coefficient is increased to compensate for the AOD underpredictions, whereas the absorption coefficient remains the same as in the control run, so that the aerosol SSA is increased. This assumption, for example, could represent a case study of the underrepresented hygroscopic growth of aerosol particles postulated in other studies for this region (Pan et al., 2015). Comparing Cases I and II will help to illuminate the impact due to uncertainty in modeled aerosol absorption profiles when the model representation of aerosol extinction profiles is comparable to observations.

As Fig. 1c shows, the zonal-mean AOD comparison with the MODIS observations as a function of latitude is much improved in the sensitivity studies with the adjusted extinction profiles (red dot-dashed line). The domain-averaged mean AOD is higher at 0.31 compared to the base case value of 0.12 , and only about $11 \%$ lower than that obtained from the MODIS retrieval (0.35). Similarly, adjustment of the extinction profiles also leads to significant improvement in the comparison with MPL and CALIPSO vertical profiles (Fig. 2 and Table 1). Below $850 \mathrm{hPa}$, the average percentage differences from the CALIPSO extinction profiles decrease to $-12,-11$, and $-30 \%$ for Nainital, Kanpur, and South Asia, respectively. The mean errors averaged through the entire column also decrease to $-22,-14$, and $-40 \%$, respectively.

Some of the remaining differences between the calculated and observed profiles in the sensitivity studies can be attributed to uncertainty associated with column AOD retrievals by CALIPSO. When the CALIPSO extinction profiles are normalized to the MODIS AOD data, the differences between modeled and observed extinction profiles averaged over the South Asia domain (Fig. 2c and f) are decreased to $-16 \%$ for the entire column and $-0.4 \%$ below $850 \mathrm{hPa}$ (Table 1). This confirms that the bias correction method introduced in the sensitivity studies compares better with the observed extinction profiles on the regional scale. On the other hand, the CALIPSO profile normalized to the column integral of the MPL-retrieved extinctions at Kanpur results in even larger AOD, thus enlarging the discrepancy from the predicted extinction profile to $-33 \%$. At Nainital, normalization makes little difference, because the surface and satellite retrievals of column AOD agree well at this site. Overall, at both ground sites and on the regional mean, the simulations of aerosol extinctions, particularly near the surface (below $2-3 \mathrm{~km}$ ), are significantly improved in the sensitivity studies, compared to the control run. Furthermore, Table 2 shows that, for various regions in South Asia, the estimated mean extinction height $z_{\alpha}$ for the adjusted extinction profiles in the sensitivity studies is generally lowered by about $10-20 \%$. This also results in better agreement with the CALIPSO-inferred mean extinction heights. In the sections below, radiative and thermodynamic responses to these improved aerosol extinction profiles are discussed.
Table 3. Aerosol-induced changes in shortwave radiation flux calculated by the WRF-Chem model in the control run and two sensitivity studies (Case I and Case II) for March 2012, averaged for $60-95^{\circ} \mathrm{E}$ and $0-36^{\circ} \mathrm{N}$.

\begin{tabular}{lrcr}
\hline & \multicolumn{3}{c}{ Aerosol-induced change $\left(\mathrm{W} \mathrm{m}^{-2}\right)$} \\
\cline { 2 - 4 } & Control run & Case I & Case II \\
\hline Top of the atmosphere & -3.0 & -4.9 & -5.4 \\
Atmosphere & +6.3 & +9.3 & +6.3 \\
Surface & -9.3 & -14.2 & -11.7 \\
\hline
\end{tabular}

\subsection{Radiative and surface temperature responses}

The buildup of aerosols in March plays an important role in modulating the distribution of solar radiation throughout the atmosphere over South Asia. In the control run, the aerosol-induced change in net downward solar radiation at the TOA is estimated at about $-3 \mathrm{~W} \mathrm{~m}^{-2}$, averaged over South Asia (Table 3), suggesting an overall cooling effect. On the other hand, aerosols heat the atmosphere by absorbing incoming solar radiation at $+6.3 \mathrm{~W} \mathrm{~m}^{-2}$. This reduces the net downward radiation at the surface (surface dimming) by $-9.3 \mathrm{~W} \mathrm{~m}^{-2}$. These estimated changes in radiation fluxes not only account for the instantaneous perturbation on radiation by aerosols (aerosol direct radiative forcing), but they also include the effects of rapid responses to aerosols at the land surface and in clouds (semi-direct radiative effects). Because aerosol extinctions (and thus AODs) in Cases I and II are increased to the same level, the TOA radiative effects of aerosols are similar for the two cases, a net reduction of about $-5 \mathrm{~W} \mathrm{~m}^{-2}$. However, the distribution of incoming solar (shortwave) radiation in the column is very different between the two cases: the estimated atmospheric absorption is $50 \%$ stronger in Case I, leading to a larger negative aerosol forcing at the surface $\left(-14.2 \mathrm{~W} \mathrm{~m}^{-2}\right)$ than in Case II $\left(-11.7 \mathrm{~W} \mathrm{~m}^{-2}\right)$.

The aerosol impact on the surface air temperature (at $2 \mathrm{~m}$ ) in the model simulations, linked directly to aerosols' perturbation of the radiation budget, is shown in Fig. 3 as a function of latitude over the land and oceans. Because the sea surface temperature is fixed, the surface air temperature over the ocean responds little to aerosol surface forcing. The near-surface air temperature responds mainly to aerosol heating and increases in the lower atmosphere over the ocean. In contrast, the absolute changes in the surface air temperature are much more significant over the land area, and they are also opposite in sign. Over land, the dominating effect of aerosols is cooling corresponding to an overall negative forcing at the TOA. The latitudinal variations in the surface air temperature changes are consistent with the AOD distribution, with a maximum up to $-0.45 \mathrm{~K}$ at around $26^{\circ} \mathrm{N}$. Of the three simulations, Case II estimates the largest cooling by aerosols at the surface, although the largest surface dimming 


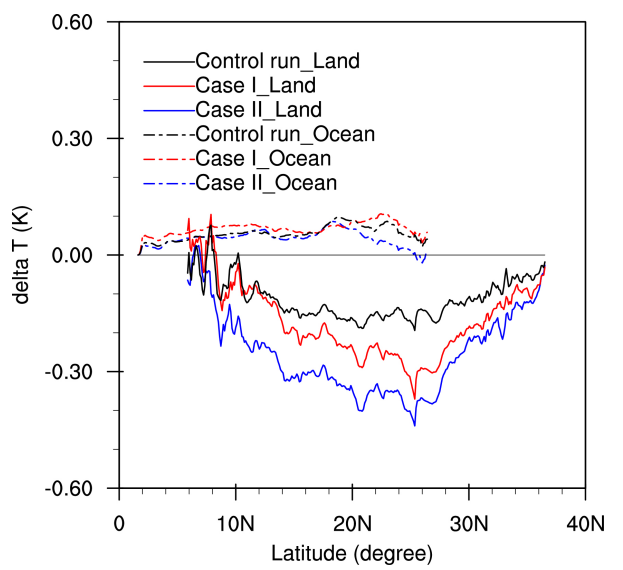

Figure 3. Changes in surface air temperature $(\mathrm{K})$ due to aerosol radiative effects for three model simulations.

of the incoming radiation is given by Case I (Table 3). This could be because aerosols over land are generally concentrated near the surface, and the aerosol-induced warming of the lower atmosphere offsets the cooling due to the surface dimming (Penner et al., 2003). Because Case I has more absorbing aerosols, the near-surface compensating heating effect is stronger, resulting in weaker surface cooling for the same AOD conditions as in Case II. The breakdown of the heating rate changes due to individual processes is discussed in the next section.

\subsection{Lower-atmosphere heating rate response}

In addition to instantaneous radiative heating due to aerosol absorption of solar radiation, rapid adjustments in the surface energy balance and BL dynamical and thermodynamical processes also influence the heating rate in the lower atmosphere. The heating rate in a volume of air or the temperature tendency term $(\mathrm{d} T / \mathrm{d} t)$ is calculated in the WRFChem model as a function of altitude for five different physical processes: shortwave (SW) and longwave (LW) radiation, BL mixing, exchange of the latent heat flux in cloud microphysics (Micro), and heat transport in cumulus (deep convection) parameterization. The differences in the calculated heating rates with and without aerosols are shown in Fig. 4 for individual processes, except that cumulus cloud parameterization - a small term at a grid spacing of $12 \mathrm{~km}$ in March - is not shown. The heating rate profiles are shown separately over the land (Fig. $4 \mathrm{a}-\mathrm{c}$ ) and oceans (Fig. $4 \mathrm{~d}-\mathrm{f}$ ). The land-ocean contrast is evident in SW heating rates that are much more significant over land because of higher aerosol loadings. The SW heating over the ocean peaks at more elevated levels, mostly above $\sim 900 \mathrm{hPa}$, not as close to the surface as over the continental source regions. Since the sea surface temperature is fixed in the simulations, stronger loweratmosphere thermodynamic responses (indicated by larger heating rates) are estimated over the land than over the ocean for BL and LW process.

Consistent with the atmospheric forcing shown in Table 3, Case I estimates the largest diurnal mean SW heating rate (maximum $\sim 0.7 \mathrm{Kday}^{-1}$ ) of the three cases, and the SW heating rate in Case II is similar to that for the control run (maximum $\sim 0.35 \mathrm{~K} \mathrm{day}^{-1}$ ). Forced by the same aerosol extinction profiles with the bias correction, the differences in calculated heating rates for individual processes between Case I and Case II are shown in Fig. 4. These results demonstrate the impact of different absorbing aerosol profiles on boundary layer dynamics and cloud microphysics processes. The BL cooling is initiated as a dynamical response to both surface dimming and atmospheric heating by aerosols. Because the simulated aerosol effects reduce the temperature gradient between the land and atmosphere, the surface buoyancy production is reduced. This leads to the suppression of the convection in the BL that transports the heat fluxes, causing the cooling. Over land, the local maximum cooling due to BL mixing occurs at the height with the largest SW heating; the larger SW heating in Case I also drives stronger BL cooling than in Case II. The LW radiation responds similarly to surface dimming and atmosphere heating, so Case I estimates the largest LW cooling over land. Over the ocean, the LW responses are also affected by cloud microphysics processes (i.e., the subsequent latent heat flux exchanges from cloud condensation and evaporation (Micro)). Because absorbing aerosols tend to stabilize the lower atmosphere and suppress the cloud formation, Case I estimates a smaller Micro heating rate at the cloud condensation level and also a smaller LW heating (cooling) below (above) the cloud layer over the ocean than Case II.

The total aerosol impact on the lower-atmosphere temperature profile is determined by the combined effects of all the heating rates (solid black line in Fig. 4). Over the ocean, the total heating rate is strongly governed by the SW heating. Thus, Case I calculates the most significant atmospheric heating by aerosols, which warms most of the lower atmosphere below $600 \mathrm{hPa}$. The maximum heating occurs below the level where the SW heating rate peaks, because of compensating LW cooling by lower marine clouds. The heating response is different over land. The calculated total heating rate deviates from the SW heating profile in the lower atmosphere as a result of rapid thermodynamic adjustments over the land surface and through BL mixing. Aerosols tend to have an overall cooling effect (negative heating rate) near the surface that exceeds the direct instantaneous SW radiative heating. The surface cooling rate is enhanced from $\sim-0.4 \mathrm{~K} \mathrm{day}^{-1}$ in the control run to $-0.7 \mathrm{~K} \mathrm{day}^{-1}$ in Case I and $-0.8 \mathrm{~K} \mathrm{day}^{-1}$ in Case II after aerosol extinctions are increased nearly to the observed levels.

Furthermore, sensitivity studies of unconstrained partitioning between absorbing and scattering components of aerosols (Case I vs. Case II) show that higher atmospheric heating due to a larger absorption fraction (as in Case I) off- 
(a) Control run: land

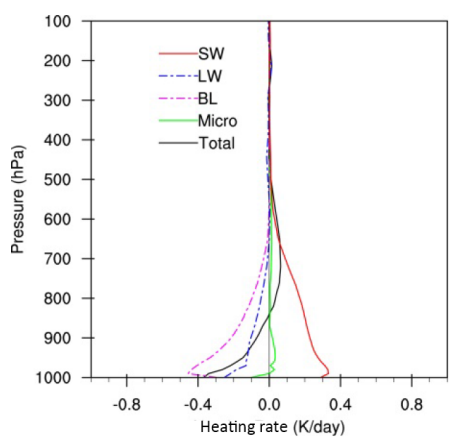

(d) Control run: ocean

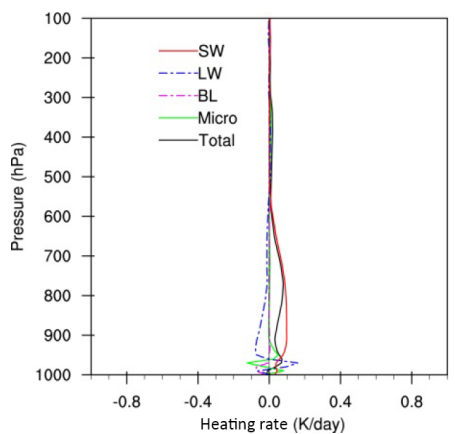

(b) Case I: land

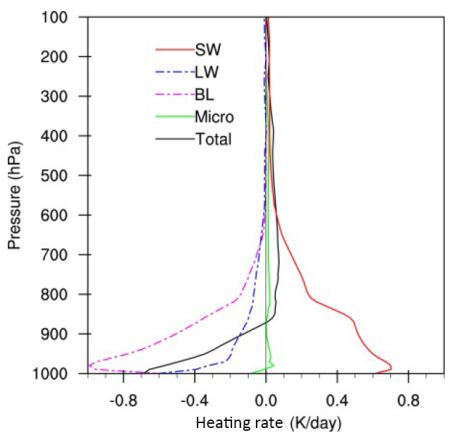

(e) Case I: ocean

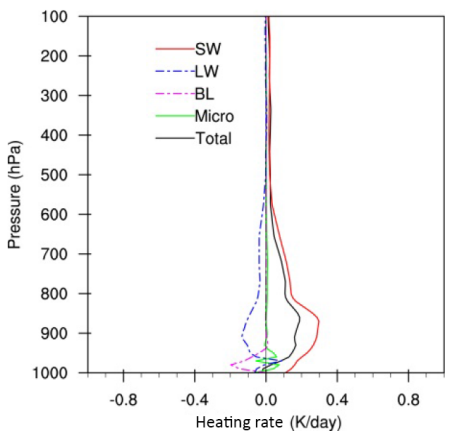

(c) Case II: land

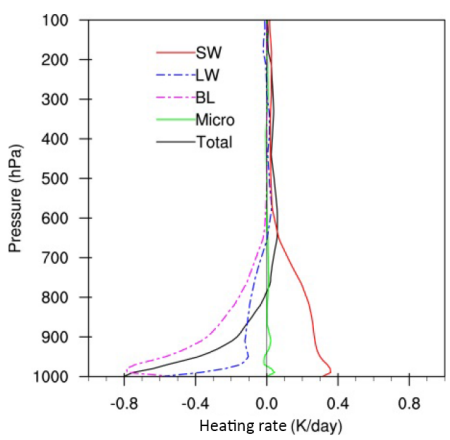

(f) Case II: ocean

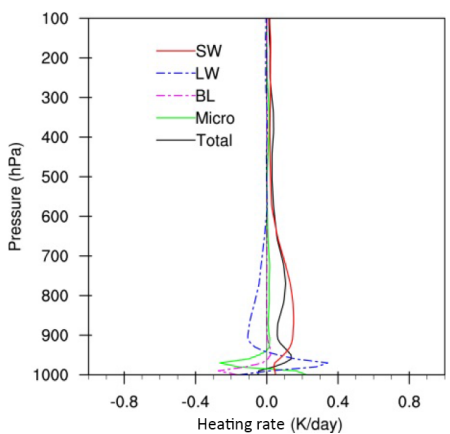

Figure 4. Calculated monthly mean heating rates (temperature tendency, $\mathrm{d} T / \mathrm{d} t$, in $\mathrm{K} \mathrm{day}^{-1}$ ) perturbed by aerosols, over land for (a) the control run, (b) Case I, and (c) Case II, as well as over the ocean for (d) the control run, (e) Case I, and (f) Case II. The heating processes include shortwave (SW) radiation (red), longwave (LW) radiation (blue dashed), boundary mixing (BL, magenta dashed), and cloud microphysics (Micro, green). The total heating due to aerosol effects is shown with solid black lines.

sets part of the near-surface BL and LW cooling responses generated, which are similar to those in Case II. Therefore, Case I warms the lower atmosphere more pronouncedly than Case II but cools less at the land surface. This implies that the manifestation of aerosol direct and semi-direct radiative effects not only depends on the aerosol extinction profile but also is affected strongly by aerosol absorption. These uncertainties in the estimated heating rates resulting from aerosol vertical distributions further propagate into simulations of the BL height and cloudiness, as discussed below.

\subsection{Atmospheric dynamic and thermodynamic responses}

As a result of changes in the heating rate, aerosol effects tend to stabilize the lower atmosphere over land. As Fig. 5 shows, the predicted BL height is lowered over most of the land areas in all three simulations compared to the run without aerosol-radiation feedbacks. The reduction in the BL height is about -10 to $-20 \%$ at locations where the estimated peak BL height (at 13:00-14:00 local time) is above 2-3 km during the pre-monsoon month. The aerosol impact on the BL height is more significant with increased AOD or extinction in the sensitivity studies, Case I and Case II, than in the control run. Moreover, more absorbing aerosols in Case I result in smaller reductions in the BL height than in Case II. This implies that the BL height is predominately linked to surface cooling. Because Case II generates the largest cooling at the surface (Fig. 3), we obtain the largest reductions in the BL heights for Case II. On some portions of the ocean and land surfaces, the BL height is moderately higher (roughly about $200 \mathrm{~m}$ ) with aerosols, and these regions correspond to areas where aerosols generally have a warming effect on the nearsurface air temperature.

Figure 6 illustrates percent changes due to aerosols in meridional circulation $(v,-\omega)$ and total precipitable water vapor (background color map) averaged at $60-95^{\circ} \mathrm{E}$. These changes are linked closely to anomalies of total heating or cooling in the atmosphere (Fig. 4). At 5-20 N, where ocean prevails, atmospheric heating by aerosols results in strengthening of the upward motion in all three model simulations, especially below $700 \mathrm{hPa}$ (Fig. 6a-c). This is accompanied by enhanced large-scale subsidence in the lower troposphere north of $20^{\circ} \mathrm{N}$, where land surface prevails and aerosols have an overall cooling effect due to strong negative $\mathrm{LW}$ and $\mathrm{BL}$ responses. The largest enhancement in the ascending zone for aerosols is in Case I, which also has the highest absorbing aerosol content. Similarly, Case II, with the strongest 
(a) Without aerosols

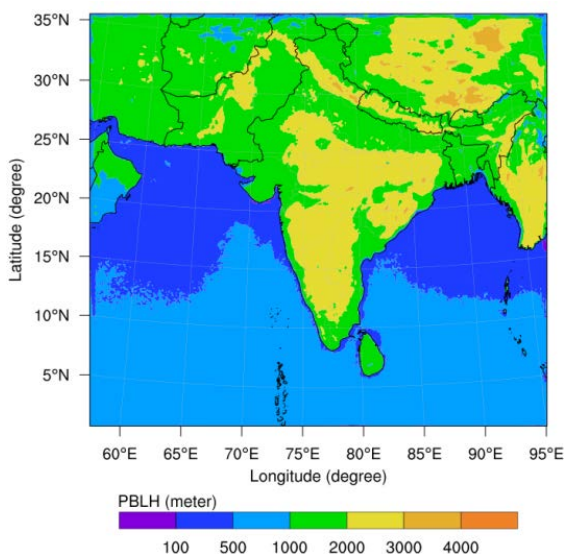

(c) Case I

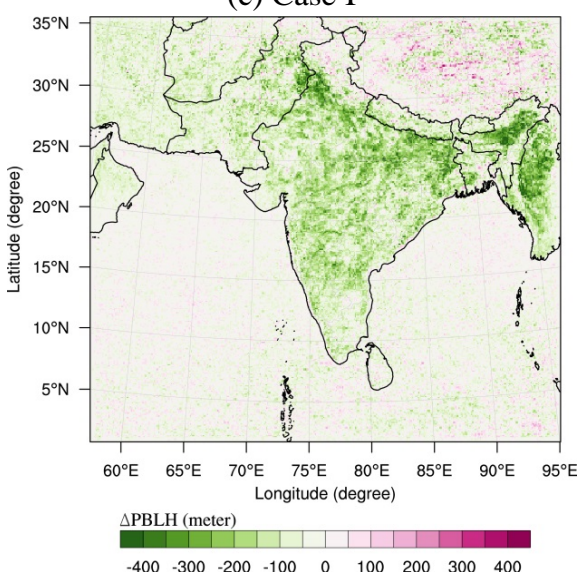

(b) Control run

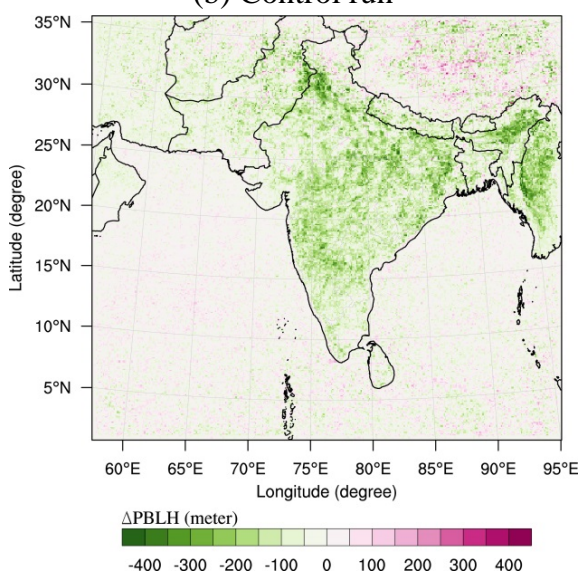

(d) Case II

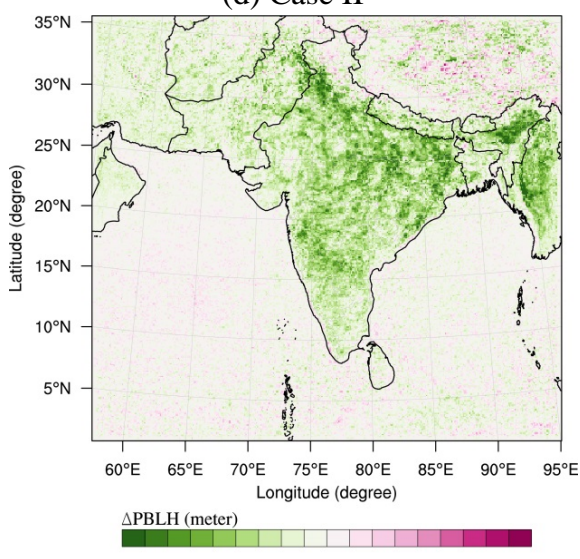

$\begin{array}{llllllllll}-400 & -300 & -200 & -100 & 0 & 100 & 200 & 300 & 400\end{array}$

Figure 5. (a) Calculated monthly mean planetary BL height (PBLH) at 13:00-14:00 local time for March, without aerosols, and estimated changes in PBLH ( $\triangle \mathrm{PBLH})$ due to aerosols in (b) the control run, (c) Case I, and (d) Case II.

cooling, calculates the largest enhancement in the descending zone.

The changes in updraft and downdraft are consistent with the aerosol-induced changes in surface pressure, as illustrated in Fig. 6d for Case I. The decreased pressure over the ocean and an increase over northern Indian subcontinent are accompanied by enhanced convergence at $850 \mathrm{hPa}$ over the Arabian Sea and enhanced divergence over the eastern Indian coast, adjacent to the Bay of Bengal. The highpressure system and divergence drive recirculation of the subsidence flow northward and form more terrain-elevated convection along the Himalayan foothills. Aerosols transported over high-elevation mountains induce a warming effect over the snow-covered surface by reducing the surface albedo, thus enhancing convective updraft over the QinghaiTibet Plateau.

In response to the radiative and dynamical perturbation, the aerosol-induced thermodynamic responses are manifested through enhanced surface evaporation and upward transport of clean, moist marine air from the northern Indian Ocean (Fig. 6a-c). The elevation of water vapor to the upper troposphere in the tropics leads to reduced moisture in the middle troposphere over the subtropics. The calculated percent changes in predicted total precipitable water vapor are very sensitive to the aerosol properties simulated. Compared with the control run, Case I predicts both larger increases of water vapor at $5-20^{\circ} \mathrm{N}$ and larger decreases of water vapor north of $20^{\circ} \mathrm{N}$ in the free troposphere, as a result of increased aerosol extinctions and AOD. On the other hand, Case II has the same aerosol extinctions and AOD as Case I but gives rise to weaker BL moistening in the tropics and stronger drying (by about $50 \%$ drier than Case I) in the middle troposphere of the subtropics $\left(>15^{\circ} \mathrm{N}\right)$, as a result of less light-absorptive aerosols.

As for water vapor, Fig. 7 shows responses in cloudiness for different aerosol simulations. Cloud frequency of occurrence is calculated as percent of hours in a month with nonzero liquid water cloud fraction below $500 \mathrm{hPa}$ in each column. In pre-monsoonal March, clouds occur more frequently over the tropical and subtropical ocean than land, in the range of 20-80\% (green contour lines in Fig. 7). Over most of the land, cloud occurrence is lower than $10 \%$, except for 
(a) Control run: $(\mathrm{v},-\omega)$ and $\Delta \mathrm{Qv}$

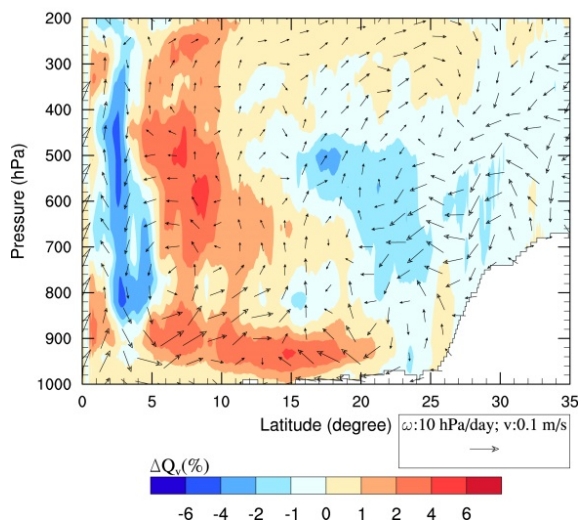

(c) Case II: $(\mathrm{v},-\omega)$ and $\Delta \mathrm{Qv}$

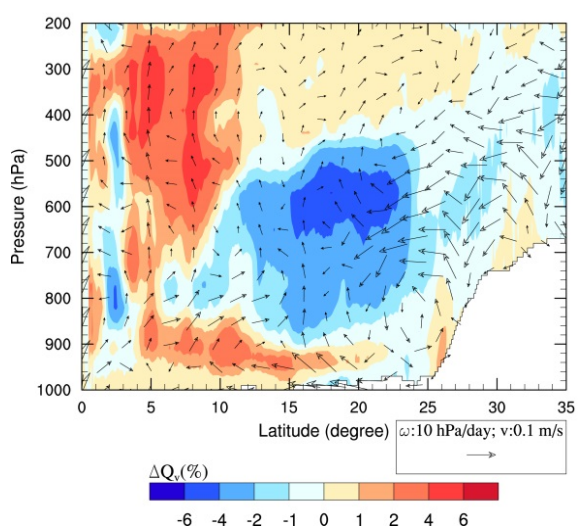

(b) Case I: $(\mathrm{v},-\omega)$ and $\Delta \mathrm{Qv}$

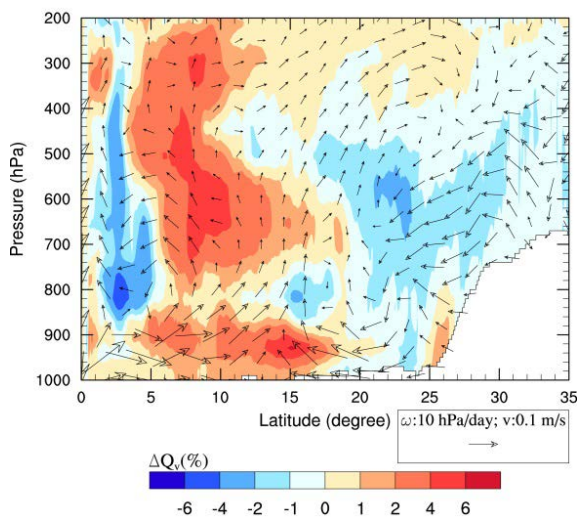

(d) Case I: (u, v) and $\triangle$ PSURF

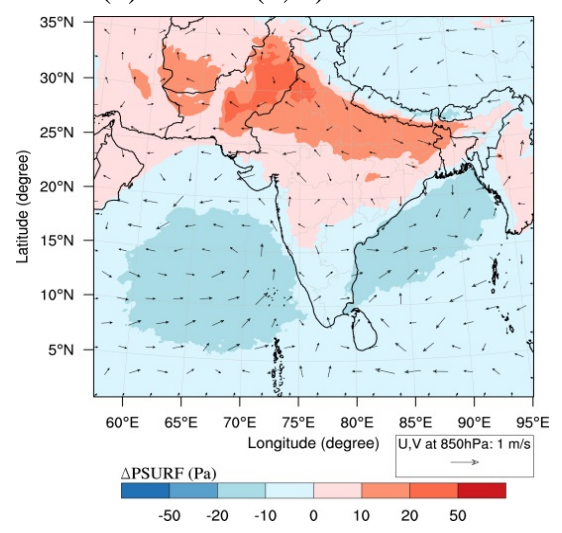

Figure 6. Changes in meridional circulation $(v,-\omega)$, averaged at $60-95^{\circ} \mathrm{E}$, due to different aerosol effects for (a) the control run, (b) Case I, and (c) Case II, where $v$ (scaled to $0.1 \mathrm{~m} \mathrm{~s}^{-1}$ ) is the meridional velocity and $-\omega$ (scaled to $10 \mathrm{hPa} \mathrm{day}^{-1}$ ) is the vertical velocity. The colorshaded contours in the background indicate the changes $(\%)$ in total precipitable water $\left(\Delta Q_{v}\right)$ in the column due to aerosols. Panel (d) shows the changes in horizontal winds $(u, v)$ at $850 \mathrm{hPa}$ and surface pressure changes $(\triangle \mathrm{PSURF})$ due to aerosols for Case $\mathrm{I}$.

the mountainous areas and over the plateau with orographic and convective cloud formation which is either not very susceptible to aerosol effects or has low aerosol concentrations. Therefore, over the polluted land surface, in spite of high aerosol loadings, cloud changes resulting from the simulated aerosol effects are small within $\pm 5 \%$ and considered as insignificant, as shown by the color map in Fig. 7a. The most significant cloud response is found over the Bay of Bengal at $10-20^{\circ} \mathrm{N}$, where the cloud occurrence exceeds $60 \%$ of the time and aerosol loadings are also high. Increased aerosol extinctions in Case I (Fig. 7b) and Case II (Fig. 7c) result in different cloud responses from the control run (Fig. 7a), which calculates a moderate increase of $5-10 \%$ in cloudiness due to aerosols. Case I enhances the aerosol effect in the control run and calculates a distinct and overwhelming increase of 10-20\% more cloudy skies over this region, whereas cloud formation in Case II is largely suppressed and aerosols are found to decrease cloudiness by about 5-10\% over some areas. Therefore, with aerosol extinctions being the same, a smaller SSA (more absorbing aerosols) in Case I could change the cloud response to aerosol radiative effects from negative to positive in pre-monsoon month, and this uncertainty in cloud response up to $10-20 \%$ could contribute to about one-third of the calculated local cloud frequency of occurrence (40-60\%).

\section{Summary and discussion}

Although aerosol radiative effects have been incorporated into global and regional climate simulations, quantification of simulated aerosol vertical distributions and subsequent climate responses in large-scale models is lacking. This is of particular importance for climate studies over South Asia, where high concentrations of aerosols are possibly linked to weakening of the South Asian monsoon in the 20th century (Bollasina et al., 2014). During March 2012, ground-based lidar measurements of vertical distributions of aerosol extinctions were made available in a polluted area of northern India, both at a high-elevation site (Nainital) near the BL top and at a valley site (Kanpur) near sea level. The aerosol extinction profiles retrieved at these two sites provide an inde- 
(a) Control run

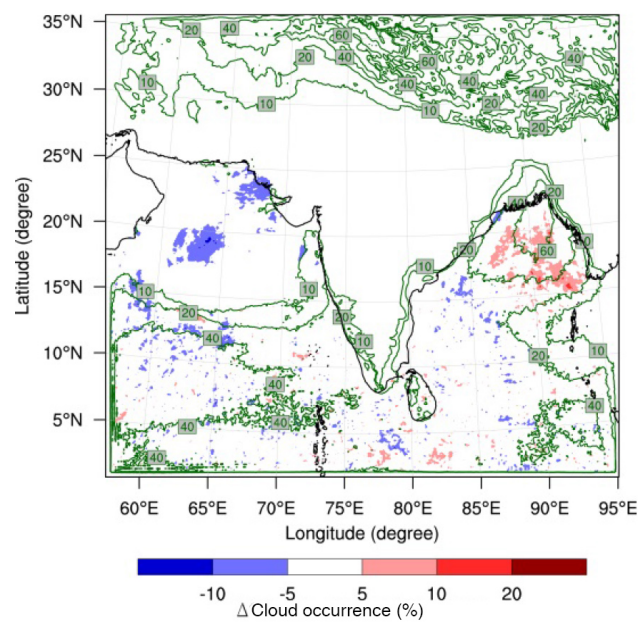

(c) Case II

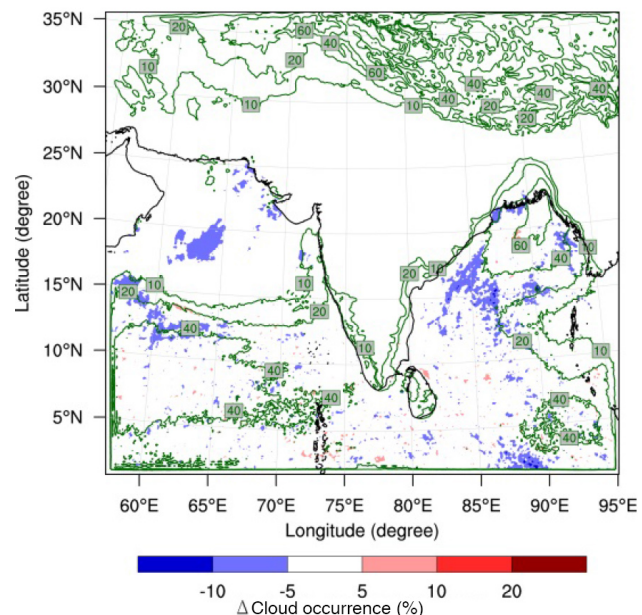

(b) Case I

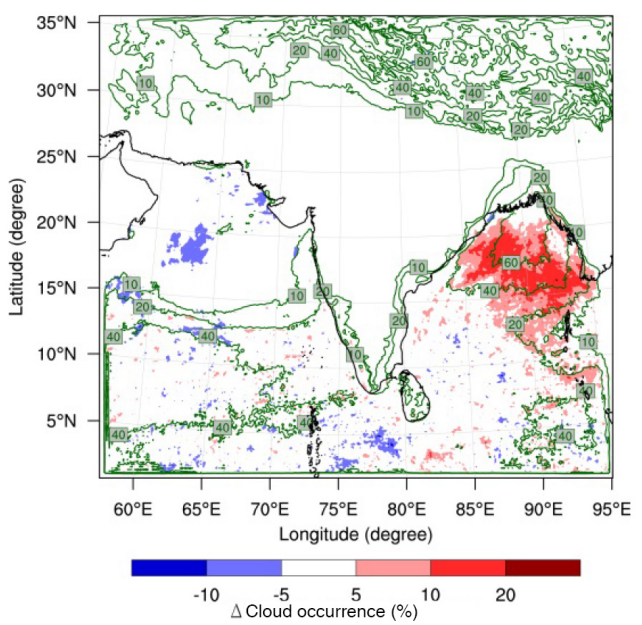

Figure 7. Changes in frequency of cloud occurrence (defined as percent of hours in a month with clouds below $500 \mathrm{hPa}$ in each column) due to aerosols for (a) the control run, (b) Case I, and (c) Case II. The contour lines in green in each panel indicate calculated frequency of cloud occurrence without aerosols. The contour levels are shown for 10, 20, 40, and $60 \%$.

pendent ground calibration of CALIPSO satellite retrievals of aerosol vertical distributions, which cover a more extended domain. Together, the profiles are used to identify altituderelated bias in WRF-Chem regional model simulations of aerosol optical properties over this region.

Our study reveals some broad tendencies and biases in model AOD simulations over South Asia. Compared to the MODIS satellite AOD, the WRF-Chem model generally underestimates AOD, despite using a high-resolution regional model with a grid spacing of $12 \mathrm{~km}$ and updated anthropogenic emissions. On a zonal or regional mean basis, the modeled AODs are underestimated by about half of the MODIS retrievals. Furthermore, we demonstrate that the low bias in column AOD is mainly associated with underprediction of aerosol extinctions in the lower troposphere vs. observed extinction profiles. Systematic underestimation of
$>50 \%$ was observed below $2-3 \mathrm{~km}$ at the two ground sites. Comparison with CALIPSO satellite data indicates even larger discrepancies of roughly $77 \%$ below $\sim 2 \mathrm{~km}$ on a regional mean basis, although some of the differences can be attributed to uncertainty associated with the CALIPSO retrievals of column AOD. Above $\sim 2 \mathrm{~km}$, the model's low bias in calculated aerosol extinction is smaller and the extent of the model underestimation also varies depending on the geographical location. Previous studies have indicated similar low bias (to different extents) in modeled column AOD (Ganguly et al., 2009; Cherian et al., 2013; Pan et al., 2015) and lower-atmosphere extinction coefficients (Yu et al., 2010; Koffi et al., 2012; Pan et al., 2015) over this region. Therefore, although the atmospheric radiative and dynamical responses derived from the sensitivity studies in this study are based on the WRF-Chem model used in this study, the depen- 
dence on aerosol extinction profiles might also be applicable to other model simulations.

Resolving the mismatch between simulated and observed aerosol extinction profiles requires possible upgrades of multiple model physics schemes and quantification of key parameters that could affect vertical distribution of aerosols, for instance, biomass burning injection heights (Grell et al., 2011), boundary layer height, and near-surface winds (Nair et al., 2012). Additionally, high-quality measurements at different locations are also needed for model evaluation over longer time periods, and it is recommended for future studies over this region. Here, instead of speculating on factors that contribute to the model-data differences, we apply a bias correction to simulated aerosol extinction profiles and demonstrate the impact on regional climate simulations. In our sensitivity studies, increases in aerosol extinction below $2-3 \mathrm{~km}$ lead to improved agreement in column AOD, from an underestimation of -66 to $-11 \%$ relative to MODIS retrievals averaged over South Asia. This suggests that about $83 \%$ of the AOD underestimation is attributable to model levels below $2-3 \mathrm{~km}$. In addition, the column-mean differences between modeled and CALIPSO extinction profiles averaged over the South Asia domain are reduced from 75 to $40 \%$ or $16 \%$ if the CALIPSO profiles are normalized to the MODIS AOD retrievals. In the aerosol-concentrated lower atmosphere below $2-3 \mathrm{~km}$, the predicted regional-mean extinction profile agrees with the CALIPSO retrieval within $30 \%$ or $0.4 \%$ compared with the CALIPSO profile normalized to the MODIS AOD.

Compared to the control run, the increased aerosol extinctions in Case I and Case II result in 63 and $80 \%$ larger negative forcing at the TOA for -4.9 and $-5.4 \mathrm{~W} \mathrm{~m}^{-2}$, respectively, and 53 and $26 \%$ stronger dimming effects at the surface for -14.2 and $-11.7 \mathrm{~W} \mathrm{~m}^{-2}$, respectively. The contrast between Case I and Case II demonstrates the importance of constraining the vertical distribution of aerosol absorption, in addition to extinction profiles. When column AOD and extinction profiles are the same as in Case I and Case II, additional absorbing aerosols (a smaller SSA) in Case I generate a $48 \%$ larger atmospheric forcing for $+9.3 \mathrm{~W} \mathrm{~m}^{-2}$.

More importantly, we demonstrate that the larger atmospheric heating and surface dimming in Case I lead to smaller lower-atmosphere cooling (up to $-0.7 \mathrm{~K} \mathrm{day}^{-1}$ ) over land than in Case II (up to $-0.8 \mathrm{Kday}^{-1}$ ); in the latter, the aerosols cause a smaller energy imbalance between the atmosphere and surface. This indicates that although absorbing aerosols generate larger radiative heating in the atmosphere, they also cause stronger cooling responses from the land surface and BL. These rapid adjustments counteract atmospheric heating and lead to overall cooling at the surface and in the lower atmosphere. The resultant cooling effect is lower than that due to fewer absorbing aerosols with the same AOD (a larger SSA).

Consequently, atmospheric dynamic and thermodynamic processes also respond differently. Case I predicts smaller reductions in BL height than Case II over land, as a result of a more stabilized lower troposphere. On the other hand, the larger atmospheric warming due to increased absorption of solar radiation in Case I increases surface evaporation from the ocean and enhances the upward convective transport of moisture into the upper troposphere in the tropics. The consequence is a reduction in the transport of moisture to the subtropical lower-to-middle troposphere during the pre-monsoon time over this region. In addition, clouds occur more frequently over the Bay of Bengal. Although the simulated aerosol perturbation is small for large-scale circulation (about $10 \mathrm{hPaday}^{-1}$ vertically, and $0.1 \mathrm{~m} \mathrm{~s}^{-1}$ in the meridional direction), water vapor $( \pm 6 \%)$, and cloud occurrence $( \pm 10 \%)$, the propagated uncertainty due to aerosol extinction is comparable to the absolute aerosol effect, and the partitioning of absorbing and scattering aerosols could change the sign of these responses.

In this work, we had to limit the evaluation of model vertical extinction profiles to 1 month, because of the need for ground-based vertical profile observations at different locations and times to validate and supplement the CALIPSO satellite retrievals. It would be desirable to conduct similar evaluations for longer times and use ensemble members of perturbed meteorological conditions to better investigate the climate response to uncertainties in modeled aerosols. In addition, observational constraints on aerosol absorption profiles are lacking. In particular, light absorption by brown carbon aerosols from biomass burning, which are important aerosol sources in South Asia, might contribute additional aerosol absorption (Feng et al., 2013). This absorption enhancement is not considered in this version of the WRFChem model used for this study and evaluated. Also, model simulations of semi-direct aerosol effects depend strongly on the model representation of clouds, which is not examined here; on the other hand, cloud occurrences are generally low over this region during the pre-monsoon month.

Nevertheless, this study improves the understanding of model underestimation of aerosols, in particular their vertical distribution over South Asia, and highlights the importance of accurate representation of both aerosol extinction and absorption profiles in regional climate simulations. Determining whether aerosol scattering or absorption contributes to the aerosol optical underestimation is critical, because the two sensitivity studies here reveal different responses in predicted large-scale dynamics and in subsequent water vapor and cloud distributions. Additional high-quality, routine measurements of both aerosol extinction and absorption profiles are needed. Furthermore, we show that rapid adjustments in the land surface energy budget and atmospheric dynamics modulate the instantaneous radiative perturbation by aerosols with comparable force and can either amplify or offset the direct aerosol radiative forcing. Our results thus reinforce the need for observational constraints of effective radiative forcing, which includes both direct and semi-direct radiative effects, for quantifying aerosol-radiation interac- 
tions, as suggested in the Intergovernmental Panel on Climate Change Fifth Assessment Report (Boucher et al., 2013).

\section{The Supplement related to this article is available online at doi:10.5194/acp-16-247-2016-supplement.}

Acknowledgements. This work was supported by the U.S. Department of Energy (DOE) as part of the Atmospheric System Research Program. Support for this research was provided to Y. Feng, V. R. Kotamarthi, R. Coulter, and M. Cadeddu by Argonne National Laboratory under U.S. DOE contract DE-AC02-06CH11357. C. Zhao's contribution to this study was supported by the U.S. DOE as part of the Regional and Global Climate Modeling program through contract DE-AC05-76RL01830. All of the numerical simulations were performed by using the computing cluster (Fusion) operated by the Argonne's Laboratory Computing Resource Center.

Edited by: X. Liu

\section{References}

Ban-Weiss, G., Cao, L., Bala, G., and Caldeira, K.: Dependence of climate forcing and response on the altitude of black carbon aerosols, Clim. Dynam., 38, 897-911, 2012.

Benjamin, S. G., Grell, G. A., Brown, J. M., and Smirnova, T. G.: Mesoscale weather prediction with the RUC hybrid isentropicterrain-following coordinate model, Mon. Weather Rev., 132, 473-494, 2004.

Bollasina, M. A., Ming, Y., and Ramaswamy, V.: Anthropogenic aerosols and the weakening of the South Asian summer monsoon, Science, 334, 502-505, doi:10.1126/science.1204994, 2011

Bollasina, M. A., Ming, Y., Ramaswamy, V., Schwarzkopf, M. D., and Naik, V.: Contribution of local and remote anthropogenic aerosols to the twentieth century weakening of the South Asian Monsoon, Geophys. Res. Lett., 41, 680-687, doi:10.1002/2013GL058183, 2014.

Boucher, O., Randall, D., Artaxo, P., Bretherton, C., Feingold, G., Forster, P., Kerminen, V.-M., Kondo, Y., Liao, H., Lohmann, U., Rasch, P., Satheesh, S. K., Sherwood, S., Stevens, B., and Zhang, X. Y.: Clouds and Aerosols, in: Climate Change 2013: The Physical Science Basis. Contribution of Working Group I to the Fifth Assessment Report of the Intergovernmental Panel on Climate Change, edited by: Stocker, T. F., Qin, D., Plattner, G.-K., Tignor, M., Allen, S. K., Boschung, J., Nauels, A., Xia, Y., Bex, V., and Midgley, P. M., Cambridge University Press, Cambridge, United Kingdom and New York, NY, USA, 2013.

Cherian, R., Venkataraman, C., Quaas, J., and Ramachandran, S.: GCM simulations of anthropogenic aerosol-induced changes in aerosol extinction, atmospheric heating and precipitation over India, J. Geophys. Res.-Atmos., 118, 2938-2955, doi:10.1002/jgrd.50298, 2013.

Chin, M., Ginoux, P., Kinne, S., Holben, B. N., Duncan, B. N., Martin, R. V., Logan, J. A., Higurashi, A., and Nakajima, T.: Tropospheric aerosol optical thickness from the GOCART model and comparisons with satellite and sunphotometer measurements, J. Atmos. Sci., 59, 461-483, 2002.

Choi, J.-O. and Chung, C. E.: Sensitivity of aerosol direct radiative forcing to aerosol vertical profile, Tellus B, 66, 24376, doi:10.3402/tellusb.v66.24376, 2014.

Chung, C. E., Ramanathan, V., Carmichael, G., Kulkarni, S., Tang, Y., Adhikary, B., Leung, L. R., and Qian, Y.: Anthropogenic aerosol radiative forcing in Asia derived from regional models with atmospheric and aerosol data assimilation, Atmos. Chem. Phys., 10, 6007-6024, doi:10.5194/acp-10-6007-2010, 2010.

Dey, S. and Di Girolamo, L.: A climatology of aerosol optical and microphysical properties over the Indian subcontinent from nine years (2000-2008) of Multiangle Imaging SpectroRadiometer (MISR) data, J. Geophys. Res., 115, D15204, doi:10.1029/2009JD013395, 2010.

Eck, T. F., Holben, B. N., Reid, J. S., Dubovik, O., Smirnov, A., O'Neill, N. T., Slutsker, I., and Kinne, S.: Wavelength dependence of the optical depth of biomass burning, urban, and desert dust aerosols, J. Geophys. Res., 104, 31333-31349, doi:10.1029/1999JD900923, 1999.

Emmons, L. K., Walters, S., Hess, P. G., Lamarque, J.-F., Pfister, G. G., Fillmore, D., Granier, C., Guenther, A., Kinnison, D., Laepple, T., Orlando, J., Tie, X., Tyndall, G., Wiedinmyer, C., Baughcum, S. L., and Kloster, S.: Description and evaluation of the Model for Ozone and Related chemical Tracers, version 4 (MOZART-4), Geosci. Model Dev., 3, 43-67, doi:10.5194/gmd3-43-2010, 2010.

Fast, J. D., Gustafson Jr., W. I., Easter, R. C., Zaveri, R. A., Barnard, J. C., Chapman, E. G., and Grell, G. A.: Evolution of ozone,particulates, and aerosol direct forcing in an urban area using anew fully-coupled meteorology, chemistry, and aerosol model, J. Geophys. Res., 111, D21305, doi:10.1029/2005JD006721, 2006.

Feng, Y., Ramanathan, V., and Kotamarthi, V. R.: Brown carbon: a significant atmospheric absorber of solar radiation?, Atmos. Chem. Phys., 13, 8607-8621, doi:10.5194/acp-13-8607-2013, 2013.

Feng, Y., Cadeddu, M., Kotamarthi, V. R., Renju, R., and Suresh Raju, C.: Humidity Bias and Effect on Simulated Aerosol Optical Properties during the Ganges Valley Experiment, Current Science, in review, 2016.

Ganguly, D., Ginoux, P., Ramaswamy, V., Winker, D. M., Holben, B. N., and Tripathi, S. N.: Retrieving the composition and concentration of aerosols over the Indo-Gangetic basin using CALIOP and AERONET data, Geophys. Res. Lett., 36, L13806, doi:10.1029/2009GL038315, 2009.

Ganguly, D., Rasch, P. J., Wang, H., and Yoon, J.: Climate response of the South Asian monsoon system to anthropogenic aerosols, J. Geophys. Res., 117, D13209, doi:10.1029/2012JD017508, 2012.

Gautam, R., Hsu, N. C., and Lau, K.-M.: Premonsoon aerosol characterization and radiative effects over the Indo-Gangetic Plains: Implications for regional climate warming, J. Geophys. Res., 115, D17208, doi:10.1029/2010JD013819, 2010.

Giles, D. M., Holben, B. N., Tripathi, S. N., Eck, T., Newcomb, W., Slutsker, I., Dickerson, R., Thompson, A., Mattoo, S., Wang, S., Singh, R., Sinyuk, A., and Schafer, J.: Aerosol properties over the Indo-Gangetic Plain: A mesoscale perspective from the TIGERZ experiment, J. Geophys. Res., 116, D18203, doi:10.1029/2011JD015809, 2011. 
Ginoux, P., Chin, M., Tegen, I., Prospero, J. M., Holben, B., Dubovik, O., and Lin, S. J.: Sources and distributions of dust aerosols simulated with the GOCART model, J. Geophys. Res.Atmos., 106, 20255-20273, 2001.

Grell, G., Freitas, S. R., Stuefer, M., and Fast, J.: Inclusion of biomass burning in WRF-Chem: impact of wildfires on weather forecasts, Atmos. Chem. Phys., 11, 5289-5303, doi:10.5194/acp11-5289-2011, 2011.

Grell, G. A., Peckham, S. E., Schmitz, R., McKeen, S. A., Frost, G., Skamarock, W. C., and Eder, B.: Fully coupled "online" chemistry within the WRF model, Atmos. Environ., 39, 6957-6975, 2005.

Haywood, J. M. and Shine, K. P.: Multi-spectral calculations of the direct radiative forcing of tropospheric sulphate and soot aerosols using a column model, Q. J. Roy. Meteorol. Soc., 123, 19071930, 1997.

Holben, B. N., Eck, T. F., Slutsker, I., Tanre, D., Buis, J. P., Setzer, A., Vermote, E., Reagan, J. A., Kaufman, Y. J., Nakjima, T., Lavenu, F., Jankowiak, I., and Smirnov, A.: AERONET - A federated instrument network and data archive for aerosol characterization, Remote Sens. Environ., 66, 1-16, 1998.

Iacono, M. J., J. S. Delamere, E. J. Mlawer, M. W. Shephard, S. A. Clough, and Collins, W. D.: Radiative forcing by long-lived greenhouse gases: Calculations with the AER radiative transfer models, J. Geophys. Res., 113, D13103, doi:10.1029/2008JD009944, 2008.

Jacob, D. J., Crawford, J. H., Maring, H., Clarke, A. D., Dibb, J. E., Emmons, L. K., Ferrare, R. A., Hostetler, C. A., Russell, P. B., Singh, H. B., Thompson, A. M., Shaw, G. E., McCauley, E., Pederson, J. R., and Fisher, J. A.: The Arctic Research of the Composition of the Troposphere from Aircraft and Satellites (ARCTAS) mission: design, execution, and first results, Atmos. Chem. Phys., 10, 5191-5212, doi:10.5194/acp-10-5191-2010, 2010.

Janjic, Z. I.: The Step-Mountain Eta Coordinate Model: Further developments of the convection, viscous sublayer, and turbulence closure schemes, Mon. Weather Rev., 122, 927-945, 1994.

Kafle, D. N. and Coulter, R. L.: Micropulse Lidar Derived Aerosol Optical Depth Climatology at ARM Sites Worldwide, J. Geophys. Res., 118, 7293-7308, doi:10.1002/jgrd.50536, 2013.

Kinne, S., Schulz, M., Textor, C., Guibert, S., Balkanski, Y., Bauer, S. E., Berntsen, T., Berglen, T. F., Boucher, O., Chin, M., Collins, W., Dentener, F., Diehl, T., Easter, R., Feichter, J., Fillmore, D., Ghan, S., Ginoux, P., Gong, S., Grini, A., Hendricks, J., Herzog, M., Horowitz, L., Isaksen, I., Iversen, T., Kirkevåg, A., Kloster, S., Koch, D., Kristjansson, J. E., Krol, M., Lauer, A., Lamarque, J. F., Lesins, G., Liu, X., Lohmann, U., Montanaro, V., Myhre, G., Penner, J., Pitari, G., Reddy, S., Seland, O., Stier, P., Takemura, T., and Tie, X.: An AeroCom initial assessment - optical properties in aerosol component modules of global models, Atmos. Chem. Phys., 6, 1815-1834, doi:10.5194/acp-6-1815-2006, 2006.

Klett, J. D.: Stable analytical inversion solution for processing lidar returns, Appl. Optics, 20, 211-220, 1981.

Koch, D., Schulz, M., Kinne, S., McNaughton, C., Spackman, J. R., Balkanski, Y., Bauer, S., Berntsen, T., Bond, T. C., Boucher, O., Chin, M., Clarke, A., De Luca, N., Dentener, F., Diehl, T., Dubovik, O., Easter, R., Fahey, D. W., Feichter, J., Fillmore, D., Freitag, S., Ghan, S., Ginoux, P., Gong, S., Horowitz, L., Iversen, T., Kirkevåg, A., Klimont, Z., Kondo, Y., Krol, M., Liu,
X., Miller, R., Montanaro, V., Moteki, N., Myhre, G., Penner, J. E., Perlwitz, J., Pitari, G., Reddy, S., Sahu, L., Sakamoto, H., Schuster, G., Schwarz, J. P., Seland, Ø., Stier, P., Takegawa, N., Takemura, T., Textor, C., van Aardenne, J. A., and Zhao, Y.: Evaluation of black carbon estimations in global aerosol models, Atmos. Chem. Phys., 9, 9001-9026, doi:10.5194/acp-9-9001-2009, 2009.

Koffi, B., Schulz, M., Breon, F. M., Griesfeller, J., Winker, D., Balkanski, Y., Bauer, S., Berntsen, T., Chin, M. A., Collins, W. D., Dentener, F., Diehl, T., Easter, R., Ghan, S., Ginoux, P., Gong, S. L., Horowitz, L. W., Iversen, T., Kirkevåg, A., Koch, D., Krol, M., Myhre, G., Stier, P., and Takemura, T.: Application of the CALIOP layer product to evaluate the vertical distribution of aerosols estimated by global models: AeroCom phase I results, J. Geophys. Res.-Atmos., 117, D10201, doi:10.1029/2011jd016858, 2012.

Kuhlmann, J. and Quaas, J.: How can aerosols affect the Asian summer monsoon? Assessment during three consecutive premonsoon seasons from CALIPSO satellite data, Atmos. Chem. Phys., 10, 4673-4688, doi:10.5194/acp-10-4673-2010, 2010.

Kumar, R., Barth, M. C., Madronich, S., Naja, M., Carmichael, G. R., Pfister, G. G., Knote, C., Brasseur, G. P., Ojha, N., and Sarangi, T.: Effects of dust aerosols on tropospheric chemistry during a typical pre-monsoon season dust storm in northern India, Atmos. Chem. Phys., 14, 6813-6834, doi:10.5194/acp-146813-2014, 2014.

Lau, K. M., Kim, M. K., and Kim, K. M.: Asian summer monsoon anomalies induced by aerosol direct forcing: the role of the Tibetan Plateau, Clim. Dynam., 26, 855-864, 2006.

Lau, K.-M., Kim, K.-M., Hsu, C. N., and Holben, B. N.: Possible influences of air pollution, dust- and sandstorms on the Indian monsoon, WMO Bull., 58, 22-30, 2009.

Liao, H. and Seinfeld, J. H.: Effects of clouds on direct aerosol radiative forcing of climate, J. Geophys. Res., 103, 3781-3788, 1998.

Liu, X., Easter, R. C., Ghan, S. J., Zaveri, R., Rasch, P., Shi, X., Lamarque, J.-F., Gettelman, A., Morrison, H., Vitt, F., Conley, A., Park, S., Neale, R., Hannay, C., Ekman, A. M. L., Hess, P., Mahowald, N., Collins, W., Iacono, M. J., Bretherton, C. S., Flanner, M. G., and Mitchell, D.: Toward a minimal representation of aerosols in climate models: description and evaluation in the Community Atmosphere Model CAM5, Geosci. Model Dev., 5, 709-739, doi:10.5194/gmd-5-709-2012, 2012.

Loeb, N. G. and Su, W. Y.: Direct aerosol radiative forcing uncertainty based on a radiative perturbation analysis, J. Climate, 23, 5288-5293, 2010.

Lohmann, U. and Feichter, J.: Can the direct and semi-direct aerosol effect compete with the indirect effect on a global scale?, Geophys. Res. Lett., 28, 159-161, 2001.

Lu, Z., Zhang, Q., and Streets, D. G.: Sulfur dioxide and primary carbonaceous aerosol emissions in China and India, 1996-2010, Atmos. Chem. Phys., 11, 9839-9864, doi:10.5194/acp-11-98392011, 2011.

McComiskey, A., Schwartz, S., Schmid, B., Guan, H., Lewis, E., Ricchiazzi, P., and Ogren, J.: Direct aerosol forcing: Calculation from observables and sensitivities to inputs, J. Geophys. Res., 113, D09202, doi:10.1029/2007JD009170, 2008. 
Meehl, G. A., Arblaster, J. M., and Collins, W. D.: Effects of black carbon aerosols on the Indian monsoon, J. Climate, 21, 28692882, doi:10.1175/2008JCLI2362.1, 2008.

Misra, A., Tripathi, S. N., Kaul, D. S., and Welton, E. J.: Study of MPLNET-Derived Aerosol Climatology over Kanpur, India, and Validation of CALIPSO Level 2 Version 3 Backscatter and Extinction Products, J. Atmos. Ocean. Tech., 29, 1285-1294, 2012.

Moorthy, K. K., Babu, S. S., Manoj, M. R., and Satheesh, S. K.: Buildup of aerosols over the Indian Region, Geophys. Res. Lett., 40, 1011-1014, doi:10.1002/grl.50165, 2013.

Myhre, G., Berglen, T. F., Johnsrud, M., Hoyle, C. R., Berntsen, T. K., Christopher, S. A., Fahey, D. W., Isaksen, I. S. A., Jones, T. A., Kahn, R. A., Loeb, N., Quinn, P., Remer, L., Schwarz, J. P., and Yttri, K. E.: Modelled radiative forcing of the direct aerosol effect with multi-observation evaluation, Atmos. Chem. Phys., 9, 1365-1392, doi:10.5194/acp-9-1365-2009, 2009.

Myhre, G., Samset, B. H., Schulz, M., Balkanski, Y., Bauer, S., Berntsen, T. K., Bian, H., Bellouin, N., Chin, M., Diehl, T., Easter, R. C., Feichter, J., Ghan, S. J., Hauglustaine, D., Iversen, T., Kinne, S., Kirkevåg, A., Lamarque, J.-F., Lin, G., Liu, X., Lund, M. T., Luo, G., Ma, X., van Noije, T., Penner, J. E., Rasch, P. J., Ruiz, A., Seland, Ø., Skeie, R. B., Stier, P., Takemura, T., Tsigaridis, K., Wang, P., Wang, Z., Xu, L., Yu, H., Yu, F., Yoon, J.-H., Zhang, K., Zhang, H., and Zhou, C.: Radiative forcing of the direct aerosol effect from AeroCom Phase II simulations, Atmos. Chem. Phys., 13, 1853-1877, doi:10.5194/acp-13-18532013, 2013.

Nair, V. S., Solmon, F., Giorgi, F., Mariotti, L., Babu, S. S., and Moorthy, K. K.: Simulation of South Asian aerosols for regional climate studies, J. Geophys. Res., 117, D04209, doi:10.1029/2011JD016711, 2012.

Pan, X., Chin, M., Gautam, R., Bian, H., Kim, D., Colarco, P. R., Diehl, T. L., Takemura, T., Pozzoli, L., Tsigaridis, K., Bauer, S., and Bellouin, N.: A multi-model evaluation of aerosols over South Asia: common problems and possible causes, Atmos. Chem. Phys., 15, 5903-5928, doi:10.5194/acp-15-5903-2015, 2015.

Penner, J. E., Zhang, S. Y., and Chuang, C. C.: Soot and smoke aerosol may not warm climate, J. Geophys. Res., 108, 4657, doi:10.1029/2003JD003409, 2003.

Petters, M. D. and Kreidenweis, S. M.: A single parameter representation of hygroscopic growth and cloud condensation nucleus activity, Atmos. Chem. Phys., 7, 1961-1971, doi:10.5194/acp-71961-2007, 2007.

Pfister, G. G., Parrish, D. D., Worden, H., Emmons, L. K., Edwards, D. P., Wiedinmyer, C., Diskin, G. S., Huey, G., Oltmans, S. J., Thouret, V., Weinheimer, A., and Wisthaler, A.: Characterizing summertime chemical boundary conditions for airmasses entering the US West Coast, Atmos. Chem. Phys., 11, 1769-1790, doi:10.5194/acp-11-1769-2011, 2011.

Platnick, S., King, M. D., Ackerman, S. A., Menzel, W. P., Baum, B. A., Riedi, J. C., and Frey, R. A.: The MODIS cloud products: algorithms and examples from Terra, IEEE T Geosci. Remote, 41, 459-473, 2003.

Quennehen, B., Raut, J.-C., Law, K. S., Ancellet, G., Clerbaux, C., Kim, S.-W., Lund, M. T., Myhre, G., Olivié, D. J. L., Safieddine, S., Skeie, R. B., Thomas, J. L., Tsyro, S., Bazureau, A., Bellouin, N., Daskalakis, N., Hu, M., Kanakidou, M., Klimont, Z., Kupiainen, K., Myriokefalitakis, S., Quaas, J., Rumbold, S. T., Schulz,
M., Cherian, R., Shimizu, A., Wang, J., Yoon, S.-C., and Zhu, T.: Multi-model evaluation of short-lived pollutant distributions over East Asia during summer 2008, Atmos. Chem. Phys. Discuss., 15, 11049-11109, doi:10.5194/acpd-15-11049-2015, 2015.

Ramana, M. V., Ramanathan, V., Kim, D., Roberts, G. C., and Corrigan, C. E.: Albedo: Atmospheric solar absorption and heating rate measurements with stacked UAVs, Q. J. Roy. Meteor. Soc., 133, 1913-1931, 2007.

Ramanathan, V., Crutzen, P. J., Lelieveld, J., Mitra, A. P., Althausen, D., Anderson, J., Andreae, M. O., Cantrell, W., Cass, G. R., Chung, C. E., Clarke, A. D., Coakley, J. A., Collins, W. D., Conant, W. C., Dulac, F., Heintzenberg, J., Heymsfield, A. J., Holben, B., Howell, S., Hudson, J., Jayaraman, A., Kiehl, J. T., Krishnamurti, T. N., Lubin, D., McFarquhar, G., Novakov, T., Ogren, J. A., Podgorny, I. A., Prather, K., Priestley, K., Prospero, J. M., Quinn, P. K., Rajeev, K., Rasch, P., Rupert, S., Sadourny, R., Satheesh, S. K., Shaw, G. E., Sheridan, P., and Valero, F. P. J.: Indian Ocean experiment: An integrated analysis of the climate forcing and effects of the great Indo-Asian haze, J. Geophys. Res., 106, 28371-28398, 2001.

Ramanathan, V., Chung, C., Kim, D., Bettge, T., Buja, L., Kiehl, J. T., Washington, W. M., Fu, Q., Sikka, D. R., and Wild, M.: Atmospheric brown clouds: Impacts on South Asian climate and hydrological cycle, P. Natl. Acad. Sci. USA, 102, 5326-5333, 2005.

Ramanathan, V., Ramana, M. V., Roberts, G., Kim, D., Corrigan, C., Chung, C., and Winker, D.: Warming trends in Asia amplified by brown cloud solar absorption, Nature, 448, 575-578, doi:10.1038/nature06019, 2007.

Samset, B. H., Myhre, G., Schulz, M., Balkanski, Y., Bauer, S., Berntsen, T. K., Bian, H., Bellouin, N., Diehl, T., Easter, R. C., Ghan, S. J., Iversen, T., Kinne, S., Kirkevåg, A., Lamarque, J.F., Lin, G., Liu, X., Penner, J. E., Seland, Ø., Skeie, R. B., Stier, P., Takemura, T., Tsigaridis, K., and Zhang, K.: Black carbon vertical profiles strongly affect its radiative forcing uncertainty, Atmos. Chem. Phys., 13, 2423-2434, doi:10.5194/acp-13-24232013, 2013.

Satheesh, S. K., Moorthy, K. K., Babu, S. S., Vinoj, V., and Dutt, C. B. S.: Climate implications of large warming by elevated aerosol over India, Geophys. Res. Lett., 35, L19809, doi:10.1029/2008GL034944, 2008.

Satheesh, S. K., Moorthy, K. K., Babu, S. S., Vinoj, V., Nair, V. S., Beegum, S. N., Dutt, C. B. S., Alappattu, D. P., and Kunhikrishnan, P. K.: Vertical structure and horizontal gradients of aerosol extinction coefficients over coastal India inferred from airborne lidar measurements during the Integrated Campaign for Aerosol, Gases and Radiation Budget (ICARB) field campaign, J. Geophys. Res., 114, D05204, doi:10.1029/2008JD011033, 2009.

Schmid, B., Michalsky, J., Halthore, R., Beauharnois, M., Harrison, L., Livingston, J., Russell, P., Holben, B., Eck, T., and Smirnov, A.: Comparison of aerosol optical depth from four solar radiometers during the fall 1997 ARM intensive observation period, Geophys. Res. Lett., 26, 2725-2728, doi:10.1029/1999GL900513, 1999.

Schwarz, J. P., Spackman, J. R., Gao, R. S., Watts, L. A., Stier, P., Schulz, M., Davis, S. M., Wofsy, S. C., and Fahey, D. W.: Global-scale black carbon profiles observed in the remote atmosphere and compared to models, Geophys. Res. Lett., 37, L18812, doi:10.1029/2010GL044372, 2010. 
Shindell, D. T., Lamarque, J.-F., Schulz, M., Flanner, M., Jiao, C., Chin, M., Young, P. J., Lee, Y. H., Rotstayn, L., Mahowald, N., Milly, G., Faluvegi, G., Balkanski, Y., Collins, W. J., Conley, A. J., Dalsoren, S., Easter, R., Ghan, S., Horowitz, L., Liu, X., Myhre, G., Nagashima, T., Naik, V., Rumbold, S. T., Skeie, R., Sudo, K., Szopa, S., Takemura, T., Voulgarakis, A., Yoon, J.-H., and Lo, F.: Radiative forcing in the ACCMIP historical and future climate simulations, Atmos. Chem. Phys., 13, 2939-2974, doi:10.5194/acp-13-2939-2013, 2013.

Skamarock, W. C., Klemp, J. B., Dudhia, J., Gill, D. O., Barker, D. M., Wang, W., and Powers, J. G.: A description of the advanced research WRF version 3, NCAR Tech. Note, NCAR/TN475+STR, Natl. Cent. for Atmos. Res., Boulder, Colo, available at: http://www2.mmm.ucar.edu/wrf/users/docs/arw_v3.pdf (last access: 8 January 2016), 2008.

Smirnov, A., Holben, B. N., Eck, T. F., Dubovik, O., and Slutsker, I.: Cloud screening and quality control algorithms for the AERONET data base, Remote Sens. Environ., 73, 337-349, 2000.

Thompson, G., Field, P. R., Rasmussen, R. M., and Hall, W. D.: Explicit Forecasts of Winter Precipitation Using an Improved Bulk Microphysics Scheme. Part II: Implementation of a New Snow Parameterization, Mon. Weather Rev., 136, 5095-5115, 2008.

Vuolo, M. R., Schulz, M., Balkanski, Y., and Takemura, T.: A new method for evaluating the impact of vertical distribution on aerosol radiative forcing in general circulation models, Atmos. Chem. Phys., 14, 877-897, doi:10.5194/acp-14-877-2014, 2014.

Wang, C., Kim, D., Ekman, A. M. L., Barth, M. C., and Rasch, P. J.: Impact of anthropogenic aerosols on Indian summer monsoon, Geophys. Res. Lett., 36, L21704, doi:10.1029/2009GL040114, 2009.

Welton, E. J. and Campbell, J. R.: Micropulse lidar signals: Uncertainty analysis, J. Atmos. Ocean. Tech., 19, 2089-2094, 2002.

Welton, E. J., Campbell, J. R., Spinhirne, J. D., and Scott III, V. S.: Global monitoring of clouds and aerosols using a network of micropulse lidar systems, Lidar Remote Sensing for Industry and Environment Monitoring, edited by: Singh, U. N., International Society for Optical Engineering (SPIE Proceedings, Vol. 4153, 151-158, doi:10.1117/12.417040, 2001.
Winker, D. M., Vaughan, M. A., Omar, A. H., Hu, Y., Powell, K. A., Liu, Z., Hunt, W. H., and Young, S. A.: Overview of the CALIPSO Mission and CALIOP Data Processing Algorithms, J. Atmos. Ocean. Tech., 26, 2310-2323, 2009.

Yevich, R. and Logan, J. A.: An assessment of biofuel use and burning of agricultural waste in the developing world, Global Biogeochem. Cy., 17, 1095, doi:10.1029/2002GB001952, 2003.

Yu, H., Dickinson, R. E., Chin, M., Kaufman, Y. J., Holben, B. N., Geogdzhayev, I. V., and Mishchenko, M. I.: Annual cycle of global distributions of aerosol optical depth from integration of MODIS retrievals and GOCART model simulations, J. Geophys. Res., 108, 4128, doi:10.1029/2002JD002717, 2003.

Yu, H. B., Chin, M., Winker, D. M., Omar, A. H., Liu, Z. Y., Kittaka, C., and Diehl, T.: Global view of aerosol vertical distributions from CALIPSO lidar measurements and GOCART simulations: Regional and seasonal variations, J. Geophys. Res., 115, D00H30, doi:10.1029/2009JD013364, 2010.

Zarzycki, C. M. and Bond, T. C.: How much can the vertical distribution of black carbon affect its global direct radiative forcing?, Geophys. Res. Lett., 37, L20807, doi:10.1029/2010g1044555, 2010.

Zhang, G. J. and McFarlane, N. A.: Sensitivity of climate simulations to the parameterization of cumulus convection in the Canadian Climate Centre general circulation model, Atmos. Ocean, 33, 407-446, 1995.

Zhao, C., Liu, X., Ruby Leung, L., and Hagos, S.: Radiative impact of mineral dust on monsoon precipitation variability over West Africa, Atmos. Chem. Phys., 11, 1879-1893, doi:10.5194/acp11-1879-2011, 2011. 